\title{
GT5665
}

\section{Use of Rubber Mats to Improve the Deformation and Degradation Behavior of Rail Ballast under Cyclic Loading}

Sinniah K. Navaratnarajah, M.S. (University of Oklahoma)

PhD Student, Centre for Geomechanics and Railway Engineering;

University of Wollongong, Wollongong City, NSW 2522, Australia.

E-mail: skn999@uowmail.edu.au

(corr author) Buddhima Indraratna, Ph.D. (Alberta), FTSE, FIEAust., FASCE, FGS

Distinguished Professor of Civil Engineering and Research Director

Centre for Geomechanics and Railway Engineering;

Program Leader, ARC Centre of Excellence for Geotechnical Science and Engineering; University of Wollongong, Wollongong City, NSW 2522, Australia.

E-mail: indra@uow.edu.au

Ph: +61 24221 3046, Fax: +61 24221 3238,

\begin{abstract}
The deterioration of a rail track due to large dynamic wheel loads is inevitable over the years, and one that leads to frequent and high maintenance costs. This problem is more critical in isolated rail track locations such as bridges and tunnels where the substructure is much stiffer than the surface track assembly. One measure used to minimize track deterioration is to place geosynthetic inclusions such as rubber mats under the layer of ballast. In this study, cyclic loads from fast and heavy haul trains were simulated on stiffer track foundation conditions using a large-scale process simulation triaxial (prismoidal) apparatus (PSPTA) to investigate the
\end{abstract}


performance of ballast improved by rubber mats locally manufactured from recycled tires. The laboratory results indicate that the energy absorbing (damping) characteristics of rubber mats reduce the amount of deformation and degradation of ballast under stiffer track conditions. The study shows that rubber mats distribute the stress applied from moving trains more uniformly by increasing the effective contact area, which then reduces the dynamic amplification of applied vertical stress and contributes to much less ballast degradation.

Author keywords: Railroad ballast; Cyclic load; Rubber mat; Deformation; Degradation.

\section{Introduction}

In many countries railways are one of the dominant modes of transportation used for conveying passengers and freight. The rapid growth in population, urbanization, as well as increasing congestion in highway transport and a growing demand for energy (e.g., fuel) is forcing rail industries to implement heavier and faster railway corridors to achieve efficient and costeffective services. However, conventional ballasted tracks must be improved in order to cope with the increasing traffic induced stresses on rail tracks. Ballast is one of the key substructure elements in rail track foundation because it serves as a bed for the rail tracks, and provides stability for the substructure as it distributes the loads exerted by moving trains. It also provides better drainage and deters the growth of vegetation that might hinder track operation. Increasing dynamic stresses from the passage of trains progressively degrades and fouls the ballast layer which inevitably leads to excessive track settlement and instability, damage to the track elements, and more frequent track maintenance (Selig and Waters 1994; Indraratna et al. 2011; Sol-Sanchez et al. 2015). As an example, track maintenance is estimated to cost approximately 14-15 million dollars per annum in the State of New South Wales, Australia, just for ballast related maintenance (Hussaini et al. 2012). In the USA, the annual cost of maintenance for 
ballast tamping and surface alignment is approximately \$3,800 per kilometer (Chrismer and Davis 2000). Therefore, minimizing ballast degradation is imperative, not only to improve the effective load carrying capacity of track substructure but also to curtail maintenance costs and increase the subsequent in-service life of the railway system.

In recent years the use of resilient materials in rail tracks to reduce noise and vibration, ballast deformation, and track degradation has become increasingly popular (Marschnig and Veit 2011; Alves Costa et al. 2012; Nimbalkar et al. 2012; Indraratna et al. 2014a; Sol-Sanchez et al. 2015). There are three major types of resilient elements used in rail tracks: (i) rail pads - installed at the rail-sleeper (tie) interface, (ii) under sleeper pads - embedded beneath the tie at the tieballast interface, and (iii) ballast mats - placed underneath the ballast layer or at the ballast/concrete interface in the case of a bridge deck. The improved damping afforded by these resilient materials helps to dissipate more energy (Finegan and Gibson 1999), particularly in tracks where their placement eliminates the hard interface between components and allows the interfaces to bed into each other, thus increasing the contact area, reducing the stresses, and minimizing track damage (Indraratna et al. 2014a; Abadi et al. 2015; Sol-Sanchez et al. 2015). For many years, research work on the resilient elements in tracks has been mostly limited to studies on reducing vibration and structure-borne noise (Wettschureck 1997; Hemsworth 2000; Hanson and Singleton Jr 2006; Alves Costa et al. 2012). However, only limited studies have been carried out to investigate the effectiveness of resilient elements to reduce the unfavorable stress-strain response and degradation aspects of ballast (Johansson et al. 2008; Nimbalkar et al. 2012; Alves Ribeiro et al. 2014; Indraratna et al. 2014a; Sol-Sanchez et al. 2015).

Bridges, tunnels, elevated stations, as well as track crossings at cuts, switches and grade separation are critical locations of relatively high track modulus (Le et al. 1999; Alves Costa et 
al. 2012; Sol-Sanchez et al. 2015). Maintenance and repairs are obviously more frequent in these localized areas, and that leads to speed restrictions, stoppages, and delays ( $\mathrm{Li}$ and Davis 2005). Stiff supports reduce the resiliency of track and cause the wheel loads transfer to a lesser number of adjacent ties, which in turn increases the rail seat loads and pressure on the ballast that ultimately leads to excessive deformation and degradation (Read and Li 2006). This issue becomes even more critical for shared lines where tracks carry faster passenger trains and heavy haul trains. In terms of performance, rubber mats installed in stiffer foundations are much more efficient than mats installed in open lines (Lombaert et al. 2006; Müller 2008). In this view, large-scale triaxial tests were undertaken at the University of Wollongong, Australia to investigate the stress-strain and degradation behavior of ballast stabilized with rubber mats over a stiff subgrade boundary. This paper presents the results of large-scale testing with and without rubber mats, and its implications on ballast performance.

\section{Large-Scale Laboratory Testing}

\section{Test Materials}

The materials used in this current investigation are fresh ballast, rubber mats, and a reinforced concrete base. The fresh ballast obtained from Bombo quarry near Wollongong City is latite (volcanic) basalt, a common igneous rock that can be found along the south coast of New South Wales, Australia. These basalt aggregates are dark, fine grained, and very dense, and have sharp angular corners when blasted and quarried. The physical properties of these basalt aggregates were evaluated as per Australian Standards (AS 2758.7 2015) and are provided elsewhere (Indraratna et al. 1998). It could be concluded from their physical properties that the high strength and angular corners of these aggregates make them suitable for railway ballast, but degradation caused by the breakage of sharp corners and edges must be anticipated when it is 
used in rail tracks where faster and heavy-haul trains are operating. The fresh ballast obtained from the quarry was prepared for testing in accordance with current Australian practices (AS 2758.7 2015); laboratory samples were cleaned with water to remove any dust and clay adhering to the aggregates and dried before screening through selected sieve sizes and then mixed in the desired proportions to obtain the required particle size distribution, PSD (Fig. 1).

The rubber mats used in this study (10 mm thick) were manufactured locally from recycled tires. After removing the non-rubber components (fiber and steel cords) from the waste tires, they were shredded into rubber granulates and then encapsulated by a polyurethane elastomer compound to make layers of mats. The mechanical properties of the rubber mat and its static and dynamic properties have been evaluated as per established testing standards stipulated in DIN 45673-5 (2010) is shown in Table 1. The hard base foundation of a rail track was simulated via a reinforced concrete base $790 \mathrm{~mm}$ long, $590 \mathrm{~mm}$ wide and $150 \mathrm{~mm}$ high, which allows for a $5 \mathrm{~mm}$ clearance all around the sides of the base inside the prismoidal test chamber.

\section{Test Apparatus}

Cyclic loading tests were carried out using the large-scale process simulation prismoidal triaxial apparatus (PSPTA) at the University of Wollongong, Australia. This prototype apparatus has special features; (i) it can replicate the influence zone or the unit cell area of an Australian standard gauge heavy haul track (see Figs. 2a \& b: a diagrammatic representation modified from Indraratna et al. (2015a)); (ii) it has a true triaxial chamber where three mutually orthogonal independent principal stresses can be applied, and (iii) it has four independent moveable vertical walls which simulates the lateral movement of ballast in a real track. A photograph of this PSPTA is shown in Fig 3a. 
By exploiting the double symmetry of a straight track section (Australian standard gauge), the plan dimensions of the PSPTA $(600 \mathrm{~mm} \times 800 \mathrm{~mm})$ represent a simplified unit cell in which the side slope of the track prism and the role of shoulder ballast have not been considered. The dimensions (Fig. 2b) represent: (i) the longitudinal direction of $600 \mathrm{~mm}$ equalling the spacing of ties (i.e. along the passage of train); and (ii) the transverse direction considering $400 \mathrm{~mm}$ on either side of one rail giving a total distance of $800 \mathrm{~mm}$, i.e. effective tie length as defined by Jeffs and Tew (1991), which is one-third of the full tie length of $2400 \mathrm{~mm}$ for Australian standard gauge (Fig. 2a). A standard concrete tie (220mm wide and $200 \mathrm{~mm}$ thick; Kaewunruen (2007)) was cut to $780 \mathrm{~mm}$ in length (i.e. little less than the chamber length of $800 \mathrm{~mm}$ ) for convenient placing inside the test chamber. The same prototype width of tie with rail assembly is used to generate a comparable pressure beneath the tie at similar train axle loads simulated by the loading actuator of PSPTA. The depth of the test chamber is sufficient to accommodate the typical depth of ballast in track (i.e. $250-300 \mathrm{~mm}$ ) followed by the underlying substructure layers. It is noteworthy that no laboratory equipment is able to represent the actual depth of stratified ground beneath track, and in this study the non-displacement boundary of the PSPTA is fixed at a depth of $600 \mathrm{~mm}$.

Unlike most conventional geotechnical equipment where scaling down of particle sizes have to be carried out in relation to the cell dimensions, PSPTA is a prototype device where scale downsizing of ballast or other track elements is not required. Also, unlike traditional test rigs with a fixed rigid boundary (steel or perspex), the PSPTA with movable vertical walls can allow the lateral displacements to occur against the lateral confining pressure applied at the boundaries of the unit cell. Here, a plane strain condition is simulated by ensuring a near-zero lateral strain in the longitudinal direction (perpendicular to tie). In this respect, its use is limited to a long 
straight section of track where the assumption of plane strain condition (i.e. $\varepsilon_{2}=0$ ) is often reasonable. As the longitudinal side walls were kept restrained, the confining pressure in the longitudinal direction would vary during the test.

Although in the field, the confining pressure in the transverse direction (parallel to tie) varies when ballast starts to displace under the axle load, in this experimental procedure the lateral pressure $\left(\sigma_{3}\right)$ is held constant at $15 \mathrm{kPa}$. In ballast tracks that conform to a shallow granular foundation where the lateral confining pressure is quite small, an application of a constant confining pressure of $15 \mathrm{kPa}$ is well within the acceptable range or variation measured in typical Australian tracks (10-30 kPa; Indraratna et al. (2011)). Also, the lateral movement of ballast on either side of the transverse direction of the PSPTA is about same, whereas in an actual track the lateral movement on either side of the rail will be different due to the different geometric boundaries imposed by the side slope and shoulder ballast.

Each vertical wall in the transverse direction can independently move outward up to a maximum of $50 \mathrm{~mm}$ from the starting position. This implies a maximum transverse strain of 12.5\% which is large enough to represent actual field conditions (Indraratna et al. 2011). The hydraulic jacks connected in line with the load cell and linear variable differential transformers (LVDTs) control the lateral stress and displacement of the walls, respectively. A system of hinges and linear and roller bearings enable the walls to move laterally with minimum frictional resistance. The servo-hydraulic actuator and the attached $100 \mathrm{kN}$ capacity load cell control the cyclic vertical stress and frequency of loading (see Fig. 3a). A controller (Fig. 3b) is connected to the host computer and software (Fig. 3c) to accurately record and display (Fig. 3d) the movements and loads associated with the main actuator and four vertical walls. Data from other 
instruments such as pressure cells and potentiometers were recorded by an additional data logger (Fig. 3b) connected to the host computer.

\section{Test Procedure, Instrumentation and Data Acquisition}

Initially, the $150 \mathrm{~mm}$ thick concrete base was placed inside the testing chamber (Fig. 3e), and then tests were planned to be carried out with and without rubber mats. In the former, a rubber mat was placed on top of the concrete base (Fig. 3f). Fresh ballast was placed on top of the concrete base (if there is no mat) or on top of rubber mat placed on the concrete base, as three equal $100 \mathrm{~mm}$ thick, compacted layers. The representative ballast aggregates directly under the tie in each in $100 \mathrm{~mm}$ thick layers (top, middle and bottom) were color coded red, green, and blue; while the other aggregates below the tie were painted yellow and above the tie were painted white, in order to differentiate and better assess the degradation of ballast with depth (Fig. 3g, h, i \& j). The spray paint (non-oil based) provided a very thin coating (bright colors) on the particles, and the surface texture of the ballast was not affected. The influence on inter-particle friction is expected to be negligible in view of the benefits of having colored ballast for the purpose of visually examining the extent of degradation. Each layer of ballast was compacted to a typical field density of $1560 \mathrm{~kg} / \mathrm{m}^{3}$ (corresponding to the approximate initial void ratio, $e_{0}=0.73$ and specific gravity $G_{s}=2.7$ for ballast) by using a rubber padded vibratory compactor (Fig. 3g). The rubber padded hammer avoids or minimizes any ballast breakages during tamping. The rail-tie assembly (Fig. 3i) was then placed and centered at the top of the compacted $300 \mathrm{~mm}$ load bearing ballast layer, and the space around the tie was filled and compacted with $150 \mathrm{~mm}$ thick crib ballast (Fig. 3j). The vertical cyclic load and lateral confinements were applied as explained in the next section "Cyclic Loading". A total of 500,000 load cycles $(N)$ were applied for each test. 
The laboratory instrumentation consists of load cells, LVDTs, potentiometers, pressure cells, and settlement plates. As explained in the previous section, the vertical and lateral loads were measured using in-built load cells attached to the main actuator and hydraulic jack, respectively (Fig. 3a). Lateral deformation is based on the movement of vertical walls where LVDTs are connected between the vertical walls and the external frame (Fig. 3a). Granular soil type pressure cells (230 mm diameter by $25 \mathrm{~mm}$ high, and with a capacity of $1 \mathrm{MPa}$ ) were placed at each of the following interfaces to measure variations in pressure with depth: (i) at the ballastconcrete base interface (Fig. 3e); (ii) at the middle of the load bearing ballast layer (Fig. 3h); and (iii) at the tie-ballast interface (Fig. 3i). Vertical deformation of ballast was measured using the potentiometers (stroke $100 \mathrm{~mm}$ ) and settlement plates (Figs. 3i,j). The transducer housings and the cable leads of the instruments were encased in flexible rubber conduits to protect them from damage due to vibratory compaction of the ballast sample during preparation and during the cyclic loadings. The initial readings of all the instruments were taken before starting the actual cyclic loading phase of the tests. Thereafter, high-frequency continuous data at selected cycles $(N=100,500,1000,5,000,10,000, \ldots . . .500,000)$ were collected from all the above listed instruments using the data loggers and host computers shown in Fig 3b.

\section{Cyclic Loading}

The typical cyclic loading experienced by rail track foundations was simulated in the PSPTA. The cyclic load applied by the servo-hydraulic actuator (see Fig. 3j) through a $100 \mathrm{~mm}$ diameter cylindrical steel ram was transmitted to the ballast layer by a rail-concrete tie assembly (see Fig. 3i). The harmonic sinusoidal loading (cyclic major principal stress, $\sigma_{1 c y c}^{\prime}$ ) applied is shown in Fig. 4. Initially, a strain-controlled loading at the rate of $1 \mathrm{~mm} / \mathrm{s}$ was applied to bring the ballasttie interface stress up to the mean cyclic deviator stress $\left(\sigma_{1 \text { cyc,mean }}^{\prime}\right)$, and then a stress-controlled 
loading was applied by selecting an amplitude $(A)$ of loading $\left[A=1 / 2\left(\sigma_{1 c y c, \max }^{\prime}-\sigma_{1 c y c, \min }^{\prime}\right)\right]$. A stress-controlled load was applied in two stages: a conditioning phase where a reduced loading frequency $(f)$ of $5 \mathrm{~Hz}$ was used for 100 load cycles $(N)$ to improve contact at the tie-ballast interface and avoid losing the actuator contact with the rail top. This ensures that the different components are seated properly at their interfaces. Then a loading phase with an actual test frequency was applied for the remaining cycles. The cyclic loading minimum $\left(\sigma_{1 c y c \text {,min }}^{\prime}\right)$, maximum $\left(\sigma_{1 c y c \text {,max }}^{\prime}\right)$ and mean stresses $\left(\sigma_{1 c y c \text {,mean }}^{\prime}\right)$ and stress amplitude $(A)$ corresponding to 25 and 35-ton axle loads are shown in Fig. 4. These pressures were determined using the American Railway Engineering (AREA) method (Li and Selig 1998a) and concurred with field measurements by Indraratna et al. (2010) for coal trains with an axle load of 25-tons. The loading frequencies ( $f$ ) used this study were 15, 20, $25 \mathrm{~Hz}$ for 25-ton axle loads and 10, 15 and $20 \mathrm{~Hz}$ for 35-ton axle loads.

Lateral confinement provided by the weight of the crib and shoulder ballast in a real rail track was simulated by the vertical walls (see Fig. 3a) of the PSPTA chamber. In an actual rail track, longitudinal ballast strain is negligible (for a long straight rail track), but transverse strain is significant due to low confinement (Ishikawa et al. 2011; Indraratna et al. 2015a), therefore the vertical walls in the longitudinal direction were locked in position $\left(\varepsilon_{2}=0\right)$ and the corresponding stress exerted by the wall (intermediate principal stress, $\sigma_{2}^{\prime}$ ) was measured. The vertical walls in the transverse direction were allowed to move in the lateral direction with an applied confining stress (minor principal stress, $\sigma_{3}^{\prime}$ ) of $15 \mathrm{kPa}$, and the accompanying lateral movement $\left(\varepsilon_{3}\right)$ was measured. A summary of the laboratory test program is shown in Table 2.

\section{Results and Discussion}




\section{Vertical and Lateral Plastic Deformation}

The accumulated vertical $\left(\mathrm{S}_{\mathrm{vp}}\right)$ and lateral $\left(\mathrm{S}_{\mathrm{hp}}\right)$ plastic deformations and corresponding vertical $\left(\varepsilon_{1}\right)$ and lateral $\left(\varepsilon_{3}\right)$ plastic strains of ballast (with and without rubber mats) were measured at different loading frequencies and axle loads of 25 and 35-ton, as shown in Figs. 5a \& b, respectively. The plastic deformations were divided by the respective dimensions in the corresponding directions (vertical, $\varepsilon_{1}=S_{v p} / 300$ and lateral, $\varepsilon_{3}=S_{h p} / 800$ ) to obtain the mean strain. The plastic deformation is the residual deformation of ballast alone and was measured at the end of each selected cycle (e.g. $N=100,500,1000,5,000,10,000, \ldots \ldots . .500,000)$ by taking the average readings of the potentiometers placed on top of the tie (assuming no plastic deformation of the concrete tie) and readings from the settlement plate placed at the ballastrubber mat interface to eliminate any elastic or plastic deformation of the rubber mat itself and that of the underlying material layers (see Fig. 3j). In every load, frequency, and synthetic mat condition, the ensuing plastic deformation of ballast was very rapid up to about 10,000 load cycles, after which the rate of settlement gradually decreased when the loading reached about 100,000 cycles and then remained stable with an almost constant settlement as shown in Figs. 5a \& b. This rapid plastic deformation stemmed from different sized ballast aggregates sliding and being rearranged within the ballast mass, and also the contribution from the abrasion and attrition of sharp angular cornered fresh ballast (Indraratna and Nimbalkar 2013). During this period of rapid deformation the ballast mass becomes more compacted, and then the possibility of particle rearrangement slowly diminishes until it reaches a stable condition. Further insignificant plastic deformation can be attributed to continuous particle abrasion and large sized splitting of well confined particles due to repeated cyclic loading. 
The test results indicate that rubber mats reduce the overall plastic deformation of ballast when placed on top of a stiff base. This study reveals about $10-20 \%$ reduction in vertical plastic deformation and about 5-10\% reduction in lateral plastic deformation. However, these reductions in plastic deformation are highly dependent on the thickness, stiffness, and density of the rubber mat, and the stiffness of the formation, e.g. soft subgrade versus stiff formation (Sol-Sanchez et al. 2015). In this study, relatively dense $10 \mathrm{~mm}$ thick (static stiffness $0.2 \mathrm{~N} / \mathrm{mm}^{3}$ ) rubber mats were used on top of the concrete base. In actual practice, rubber mats are more effective when the support is stiffer, such as in tunnels and on concrete bridges (Müller 2008; Alves Costa et al. 2012). Increasing the thickness of the elastic layer or using an elastic element to reduce stiffness beyond the optimum value can cause excessive plastic deformation of ballast, as well as fatigue damage to other track components (Hunt 2005). Therefore, the thickness, stiffness, and density of a rubber mat with respect to formation stiffness are crucial in reducing the vibration and plastic deformation in ballast.

\section{Volumetric and Shear Strain Variations}

The volumetric $\left(\varepsilon_{v o l}\right)$ and shear $\left(\varepsilon_{s}\right)$ strains for the special case of plane strain test conditions (i.e., $\varepsilon_{2}=0$ ) were determined by the following equations (Timoshenko and Goodier 1970):

$$
\begin{gathered}
\varepsilon_{v o l}=\varepsilon_{1}+\varepsilon_{3} \\
\varepsilon_{s}=\frac{2}{3} \sqrt{\left(\varepsilon_{1}^{2}+\varepsilon_{3}^{2}-\varepsilon_{1} \varepsilon_{3}\right)}
\end{gathered}
$$

where, $\varepsilon_{1}$ is the vertical (major principal) strain and $\varepsilon_{3}$ is the lateral (minor principal) strain measured perpendicular to the rail. For 25 and 35-ton axle loads, the variation of $\varepsilon_{\text {vol }}$ and $\varepsilon_{s}$ with the number of cycles $(N)$ is shown in Figs. 6 (a) and (b), respectively. As explained previously, rapid volumetric and shear strains occurred up to around 10,000 cycles while the rate 
of strain slowly decreased until about 100,000 cycles, and then stabilized. Based on these results, about $10-20 \%$ reduction in the volumetric and shear strains for a 25 -ton axle and about $10-15 \%$ reduction for a 35-ton axle load was evident when rubber mats were used in track with stiff foundations.

\section{Damping Ratio (D) and Strain Energy Dissipation $\left(E_{d}\right)$}

Viscoelastic materials such as ballast exhibit hysteresis behavior under cyclic loading and unloading which dissipates the mechanical strain energy. This stored and dissipated strain energy is related to the mechanical damping of viscoelastic materials. In this study, the cyclic stressstrain curves developed from the experimental results were used to determine the damping ratio $(D)$ and the strain energy dissipation $\left(E_{d}\right)$ of ballast mass with and without a rubber mat. An example of a typical stress-strain curve obtained from testing is shown in Fig. 7(a). This plot corresponds to the last 30 hysteresis loops at the selected load cycles $(N)$. A schematic representation of a hysteresis loop and the equations used to calculate $D$ and $E_{d}$ from the hysteresis loop, as explained in ASTM D3999 (2003), is shown in Fig. 7(b). This dissipation in energy is proportional to the area within the hysteresis loop, as represented by the energy per unit volume per load-unload cycle, while the damping ratio is proportional to the ratio of the energy dissipated and stored during the loading-unloading cycle (Sitharam and Vinod 2010), as shown in Fig 7(b). Average values of the last 5 hysteresis loops at each selected cycles were used to compute the $D$ and $E_{d}$. Figs. 8(a) and (b) show the variation of $D$ and $E_{d}$ with $N$ for 25 and 35ton axle loads, respectively. These results indicate that a rubber mat increases the damping property of the substructure and leads to an increased dissipation of strain energy. Initially, both $D$ and $E_{d}$ are high and decrease with $N$ due to high energy dissipation from plastic sliding and breakage, and then these values remained almost constant as the ballast mass gets densified and 
stabilized after about 10,000 cycles. Figures 8(a) and (b) also show an increase in energy dissipation due to the increase of load and frequency (increased input energy). The subsequent dissipation of energy occurs by particle sliding and breakage that is proportional to the increased input energy.

\section{Resilient Modulus $\left(M_{R}\right)$ of Ballast}

The resilient modulus $\left(M_{R}\right)$ is one of the main parameters crucial to the analysis and design of track foundation subjected to repeated cyclic wheel loads (Li et al. 2015). $M_{R}$ is defined as:

$$
M_{R}=\frac{\sigma_{c y c}}{\varepsilon_{r}}
$$

where $\sigma_{c y c}$ is the cyclic deviator stress and $\varepsilon_{r}$ is the resilient (recoverable) strain during cyclic triaxial unloading (Indraratna et al. 2009; Sun et al. 2016). The high-frequency transient stressstrain data collected at the selected $N$ values were used to calculate $M_{R}$ of ballast; the results are shown in Figs. 9 (a) and (b) for 25 and 35-ton axle loads, respectively. As expected, and as reported by other researchers (Lackenby et al. 2007; Indraratna et al. 2009) the $M_{R}$ of ballast increased with $N$ at least up to 200,000 load cycles and then slowly stabilized after successive cycles. This increase in $M_{R}$ is attributed partly to the cyclic densification of ballast due to an increase of $\varepsilon_{\text {vol }}$ with $N$. As $\varepsilon_{\text {vol }}$ increases with $N$ (Figs. 6a, b), this reduces the void ratio which in turn increases the ballast stiffness and the progression of $M_{R}$ with $N$. It is also evident from Figs. 6 (a) and (b), that an increasing load (25 to 35-ton) and frequency (from 10 to $25 \mathrm{~Hz}$ ) leads to the ballast particles becoming more densely compacted due to an increase of $\sigma_{c y c}$ which leads to an increased $M_{R}$; this also agrees with the earlier studies by Lackenby et al. (2007) and Sun et al. (2016). This increase in frequency also allows smaller particles to move into the voids of larger particles which results in further densification of ballast (i.e., vibratory compaction) which in 
turn minimizes the resilient deformation and leads to a higher $M_{R}$ (Sun et al. 2016). This study also confirms (See Figs. 6a, b) that rubber mats improve the resilient modulus of ballast because part of the elastic strain now taken by the synthetic elastic mat placed beneath the ballast. Overall, by considering the different load and frequency tests performed in this study, $M_{R}$ of ballast improved in the order of 10 to $15 \%$ by using a rubber mat.

\section{Ballast Degradation}

The stress-strain and volume change behavior, strength and permeability characteristics of granular materials depends on the degree of particle breakage that occurs due to changes in ballast stress (Lade et al. 1996). Railway ballast undergoes significant changes in stress due to repeated cyclic and impact wheel loading and exhibits considerable particle breakage (Marsal 1967; Indraratna et al. 2011). The highly angular and sharp cornered nature of quarried ballast and the presence of micro-fissures from blasting, aggravated breakage during triaxial shearing leads to reduced angle of internal friction (i.e., strength) of the ballast mass (Marsal 1967; Lade et al. 1996; Indraratna et al. 2015b). Therefore, the significance of particle breakage on the mechanical behavior of granular particles has been recognized through numerous studies (Marsal 1967; Vesic and Clough 1968; Hardin 1985; Ueng and Chen 2000; Indraratna et al. 2011). As a consequence, various methods to quantify particle breakage have been proposed, e.g., breakage parameter $B_{g}$ by Marsal (1967), the relative breakage $B_{r}$ by Hardin (1985), ballast breakage index $B B I$ by Indraratna et al. (2005), and the breakage internal variable $B$ by Einav (2007) among others. In this study, the Ballast Breakage Index $(B B I)$ proposed by Indraratna et al. (2005) specifically for railway ballast was used. This method is simple to use, and it is based on particle size distribution (PSD) before and after testing with respect to an arbitrary boundary of 
maximum breakage, as shown in Fig. 10 (data from Indraratna et al. (2005)). The BBI in this method is defined as,

$$
B B I=\frac{A}{A+B}
$$

where, $A$ is the area of shift in the PSD curve after testing, and $B$ is the area of potential breakage, as shown in Fig 10.

Since the ballast breakage potential varies with depth, as observed by Indraratna et al. (2014b), due to changes in stress along the depth of the ballast layer, the ballast mass was divided into three layers (top, middle and bottom). These layers are corresponding to ballast breakage governed by variation in stress and interfaces (the top is the tie-ballast zone, the middle is the ballast-ballast-zone, and the bottom is the ballast-concrete base zone). To better quantify degradation in these zones, the representative fresh ballast directly under the tie was color coded (Fig. 11a) in each test, after which each layer of degraded ballast was separated based on these colors (Fig. 11b), and the PSD was plotted to evaluate their BBI. Different types of particle degradation such as grinding (abrasion), angular corner breakage (attrition) and distinct splitting across the body of particles (fracture) were observed from the degraded ballast, as shown in Fig. 11b. The quantified values of ballast degradation $(B B I)$ are presented in Fig. 12 for 25 and 35ton axle loads with varying test frequencies (10 to $25 \mathrm{~Hz}$ ) for ballast with and without a rubber mat under the ballast, i.e. on top of a hard concrete base. As expected, ballast degradation was highest in the top layer; it decreased in the middle layer, and decreased further in the bottom layer, as the induced cyclic stress decreased along the depth of ballast. There was a significant increase in ballast breakage when the load and frequency of cyclic loading increased, which agrees with other researchers who tested ballast using the more traditional (cylindrical) triaxial apparatus (Indraratna et al. 2005; Lackenby et al. 2007; Sun et al. 2016). 
Fig. 12 shows that ballast degradation decreased significantly when a rubber mat was placed on top of the hard concrete base beneath the ballast layer. When all three layers are considered, an average 35-45\% reduction of breakage was evident from the current study. When individual layers are considered, there was about 50-60\% reduction of $B B I$ at the bottom layer compared to $20-25 \%$ and $30-50 \%$ at the top and the middle layers, respectively. This clearly demonstrates how rubber mats on a hard concrete base (stiff subgrade) help to reduce ballast breakage. The $B B I$ values evaluated from a field study by Indraratna et al. (2014b) over a concrete bridge deck where a rubber mat was placed underneath the ballast layer corroborates well with the current study, as shown in Fig. 12.

\section{Ballast Stress Variation with Depth}

The pressure at the tie-ballast interface and variations in pressure along the depth of the ballast depends mainly on the stiffness of the ballast and underlying formation, the type and spacing of ties, the train speed and axle loads (Esveld 2001; Yang et al. 2009). In this study, pressure cells placed at the tie-ballast interface, in the middle of the ballast layer, and at the ballast-concrete base interface were used to measure the dynamically induced pressure variation along the depth of the ballast mass. Figs. 13 (a) and (b) show the variations in pressure for 25 and 35-ton axle loads, respectively. It is observed that the dynamically induced stresses in the ballast increased with the axle load and train speed (loading frequency). These results compare well with the limited field data obtained for a 25-ton axle load train at a speed of $73 \mathrm{~km} / \mathrm{h}(10 \mathrm{~Hz})$ by Nimbalkar and Indraratna (2016), and for experimental data obtained for a $20 \mathrm{~Hz}$ test conducted by Sun et al. (2016), as shown in Fig 13(a).

The in-situ measurements by Kempfert and $\mathrm{Hu}$ (1999) and Nimbalkar and Indraratna (2016) also confirmed that the vertical stresses increased as the axle load and train speed 
increased. When a rubber mat was placed on top of a concrete base there was a notable reduction in stress within the ballast mass. The stress amplification due to a stiff base is now curtailed by the softer interface introduced by the rubber mat between the ballast and concrete. On average, the percentage reduction of stress varied from about $1.4 \%$ at the tie-ballast interface to $20 \%$ at the ballast-concrete base interface, and about $10 \%$ at the middle of ballast layer for a 25 -ton axle load. For a 35-ton axle load, the reduction in stress was about $1.2 \%$ at the tie-ballast interface, about $10 \%$ at the ballast-concrete base interface, and about $6.5 \%$ at the middle of the ballast layer. This reduction in stress at the ballast-tie interface is not significant for ballast stabilized with a rubber mat placed beneath the ballast layer. To reduce stress at the tie-ballast interface, a rubber pad attached to the bottom of the tie is a better option (Abadi et al. 2015). When a rubber mat is used, ballast aggregates bedded better at the ballast-concrete base interface and this increased the contact area of ballast to the concrete base. This resulting reduction in stress concentration allows cyclic induced stress to be distributed over a wider area beneath the tie, and a more uniformly distributed stress helps to reduce particle degradation.

\section{Dynamic Amplification Factor}

The effect that train speed has on substructure stresses is highly complex in nature due to the dynamic interaction between the vehicle, the track, and the substructure. In conventional railway engineering practice, the dynamic amplification factor (DAF) is used to obtain equivalent dynamic stresses, where DAF is the function of a static wheel load and train speed (Li and Selig 1998b; Esveld 2001). The train speed ( $V$ ) can be expressed as a function of the loading frequency (f) using the expression $V=f \lambda$, where $\lambda$ is the characteristic length measured by the distance between two rear axles of a leading wagon and two front axles of a trailing wagon which induce maximum frequency (Indraratna et al. 2015a). Therefore, a cyclic loading frequency of 10-25 Hz 
represents a train speed of 73-182 km/h for an axle distance $(\lambda)$ of $2.02 \mathrm{~m}$ (typical heavy haul multiple axle freight wagons in the State of New South Wales). The variation of DAF within the ballast layer with varying frequency and axle load was evaluated from the ballast pressure data acquired in this present study. DAF is calculated using $D A F=\sigma_{v, c y c}^{\prime} / \sigma_{v, \text { sta }}^{\prime}$ where $\sigma_{v, \text { cyc }}^{\prime}$ is the measured dynamic stress and $\sigma_{v, s t a}^{\prime}$ is the static stress when the load is stationary, which is obtained by the following expression (Jeffs and Tew 1991):

$$
\sigma_{v, s t a}^{\prime}=\left(\frac{3 q_{r}}{B l}\right) F
$$

where $q_{r}$ is the rail seat load (e.g., for 25-ton axle load, assuming $40 \%$ rail seat load, $\left.q_{r}=0.4 \times 25 / 2 \times 9.8=49 \mathrm{kN}\right)$ and $F$ is the factor depending on the type of tie and track maintenance (for a new track $F=1$ ). The length, $l$ (varies 2.39-2.5 m) and width $B$ (varies 0.20$0.26 \mathrm{~m}$ ) of the tie depends on the type of the tie (heavy or medium duty) used in the track. Assuming, $\quad l=2.4 \mathrm{~m}$ and $B=0.26 \mathrm{~m}, \sigma_{v, s t a}^{\prime}$ have been calculated as $230 \mathrm{kPa}$ and $320 \mathrm{kPa}$ corresponding to the axle loads of 25 and 35-ton, respectively. The variation of DAF with train speed calculated within the ballast mass based on this method is illustrated in Fig. 14. As explained previously, the rubber mat reduces ballast stress, particularly in the middle and bottom layers, so a reduction of DAF with depth from the base of the tie when a mat is placed on top of the concrete base.

Fig 15 illustrates the DAF calculated at the tie-ballast interface for 25 and 35-ton axle loads with varying frequency (train speeds), together with the predictions made from other studies (Li and Selig 1998b; Esveld 2001; Nimbalkar and Indraratna 2016; Sun et al. 2016). Fig. 15 shows that conventional methods tend to over predict the DAF for a range of train speeds (frequencies) simulated in the laboratory. As noted by Esveld (2001), conventional formulae 
provide a rough approximation (usually overestimated) to reality, as they ignore some of the geometric boundaries of the track (e.g. side slopes), and also some of the mechanical characteristics of the track and vehicles are not sufficiently taken into account for the purpose of simplicity. However, the extrapolated field data curve obtained by Nimbalkar and Indraratna (2016) as well as the traditional cylindrical triaxial data by Sun et al. (2016) matched closely with the current laboratory data from the PSPTA. In view of the above, a non-linear best-fit equation expressed as:

$$
D A F=\alpha e^{\beta V}
$$

where $\alpha$ and $\beta$ are empirical parameters depending on the stiffness of the track substructure and axle load. The parameters calculated for a relatively stiff track (i.e., concrete base at the bottom of PSPTA) for 25 and 35-ton axle loads for a range of train speeds $(70-180 \mathrm{~km} / \mathrm{h})$ tested are shown in Fig. 15 with the best-fit non-linear regression coefficient, $R^{2}>0.99$. When the frequency of loading increases, the dynamic stress generated at the tie-ballast interface is significantly higher than the static loading. This increase in DAF is characteristic of the inherent dynamic response of granular materials that densify during cyclic loading (Sun et al. 2016), and the stiffness of the substructure. Amplification is more pronounced for stiff tracks such as tracks on bridges and in tunnels, and for track constructed on rocky subgrade.

\section{Influence of Damping Ratio (D), Deviator Stress $\left(q_{d}\right)$ and Resilient Modulus $\left(M_{R}\right)$ on BBI}

The behavior of granular media under relatively high stresses and corresponding degradation has been reported in classical studies by Marsal (1967) and Vesic and Clough (1968). The BBI is influenced by the change of load and frequency (change in deviator stress, $q_{d}$ ). Particle breakage also has a profound influence on the resilient modulus $\left(M_{R}\right)$ of granular materials (Indraratna et al. 2009). Due to its damping nature, rubber mats are more efficient in decreasing the rapid 
deterioration of ballast aggregates in contact with a rigid substructure (Sol-Sanchez et al. 2015). In view of this, and based on the current results, an empirical relationship between $B B I, q_{d}$, and $M_{R}$ could be formulated using MATLAB as follows:

$$
B B I=m\left(\frac{q_{d}}{M_{R}}\right)^{n}
$$

where $m$ and $n$ are empirical parameters related to the damping property $(D)$ of the granular assembly, i.e. $m=k_{1} D^{k_{2}}$ and $n=k_{3} \sqrt{D}$, where $k_{1}, k_{2}$ and $k_{3}$ are regression model parameters (see inserted table in Fig. 16 for $R^{2}>0.96$ ). The $B B I$ values predicted by the above empirical model with and without a rubber mat are in excellent agreement with those calculated from the test results as shown in Fig. 16. $M_{R}$ and BBI vary with the number of load cycles (Thakur 2011), however, BBI predicted from the current study is limited to 500,000 load cycles.

\section{Energy Dissipation Behavior}

Granular particles such as ballast consist of a large number of clearly distinguishable particles in which adjacent particles contact each other and form skeletons to support its self-weight and external forces. When the external forces increase beyond a limiting value, the particles begin to lose contact or make new contacts which creates various forms of energy transformation including elastic strain energy and kinetic energy, while a part of which dissipates due to particle sliding and breakage (Bolton et al. 2008; Bi et al. 2011; Liu et al. 2014). Quantifying energy dissipation due to particle breakage and rearrangement is a daunting task due to the complex linkage between micro- and macro-mechanical responses (Wang and Yan 2012), and further modeling difficulties introduced by different mechanisms of particle breakage (Liu et al. 2014). An empirical expression is developed in this study to quantify the total energy dissipation $\left(E_{D}\right)$ 
per unit volume of ballast by adding the corresponding dissipation terms attributed to plastic sliding $\left(E_{S}\right)$ and particle breakage $\left(E_{B}\right)$.

$$
E_{D}=E_{S}+E_{B}
$$

The first term $E_{S}$ is frictional sliding closely linked with the applied deviator stress $\left(q_{d}\right)$ and the total shear strain $\left(\varepsilon_{s}\right)$, where a larger amount of energy consumed to overcome the shear resistance of inter-particle friction (Liu et al. 2014). The second term $E_{B}$ can be related to the evolution of particle breakage BBI (Indraratna and Salim 2002). In view of that, the following empirical relationship can be formulated:

$$
\begin{gathered}
E_{S}=a\left(q_{d} \varepsilon_{s}\right) \\
E_{B}=b(\kappa \times B B I)^{c}
\end{gathered}
$$

where $a, b$, and $c$ are empirical model parameters and $\kappa$ is the axle load factor normalized to the minimum axle load $\left(L_{m}\right)$ which for Australian standard heavy haul, $L_{m}=20$-ton (i.e. $\kappa=\sqrt{L / L_{m}}$, $L$ is axle load simulated in this study). The empirical parameters $a$ and $c$ are dimensionless while $b$ takes the units of energy. As per Eqs. (10), for a standard 20-ton axle load (i.e. $\kappa=1$ ), $b=1$ $\mathrm{MJ} / \mathrm{m}^{3}$ for complete breakage (i.e. $B B I=1$ ). This energy dissipation model is corroborated to 500,000 loading cycles, which is about 1 years of service for standard heavy haul in the State of New South Wales (NSW) with an annual traffic tonnage of 50 MGT (Indraratna et al. 2011). The non-linear regression predicts energy dissipation well with the calculated model parameters shown in Fig. $17\left(R^{2}>0.98\right)$. While field data is very limited to support the above relationship between actual $\left(E_{D a}\right)$ and predicted $\left(E_{D p}\right)$, the Singleton field trial (Nimbalkar and Indraratna 2016) from the State of NSW (as marked in Fig. 17) where a rubber mat was placed on top of the concrete bridge deck provided very good agreement for heavy haul traffic (50 MGT) over 
500,000 cycles at an average train speed of $70-80 \mathrm{~km} / \mathrm{h}$ (approx. equivalent to $10 \mathrm{~Hz}$ in laboratory testing).

\section{Conclusions}

The performance of ballasted track stabilized with rubber mats on a very stiff subgrade (i.e. on concrete bridge deck or in a rock tunnel) was evaluated using large-scale (prototype) laboratory testing under cyclic loading with varying frequencies and axle loads. The results confirmed that ballast on a stiff foundation stabilized by rubber mats experienced considerably less deformation and degradation. The vertical and lateral plastic deformation and breakage of ballast increased with the axle loads and train speed (loading frequency). Rapid plastic deformation occurred up to about 10,000 load cycles, and then the rate of deformation gradually diminished and the corresponding strains became marginal when the ballast medium stabilized after about 100,000 cycles. When rubber mats were placed beneath the ballast layer, i.e. on top of the concrete base, about $10-20 \%$ reduction in vertical plastic strain and 5-10\% reduction in lateral plastic strain were observed as favorable outcomes.

This study also confirmed that particle breakage was highest at the top of the ballast layer followed by the middle and bottom layers because the stresses in the top layer induced by the applied load were much higher. On average, the overall degradation of ballast decreased by about 35-45\% when rubber mats were placed beneath the ballast. The percentage reduction in breakage was highest (50-60\%) in the bottom layer, i.e. ballast-concrete base interface where the rubber mat plays a significant role by distributing the applied stress more uniformly and attenuating the dynamic amplification of applied stress. Up to $20 \%$ reduction of vertical stress at the ballast-concrete base interface was evident. Reducing the ballast degradation could directly influence track longevity because it decreases the frequency of track maintenance. This study 
confirmed that recycled rubber mats used herein had an adequate damping ratio to absorb the energy transmitted to the track, thus preventing excessive ballast degradation.

The results of this study have shown beyond doubt that the energy absorbing capacity or damping characteristics of rubber mats enables the ballast layer to attain a more stable state with less breakage and deformation corresponding to a relatively constant resilient modulus after about 300,000 cycles of loading. The empirical model developed to predict the ballast breakage index $(B B I)$ and energy dissipation $\left(E_{D}\right)$ during cyclic loading is shown to be in good agreement with the laboratory results.

In terms of national benefits, manufacturing these mats from recycled rubber tires would reduce their volume at spoil tips and contribute to more effective land use, especially in expensive urban suburbs. Moreover, a substantial reduction in ballast breakage and extended track longevity would embrace blatant 'green' implications (i.e. less quarrying and environmental degradation) while accruing substantial annual savings to the owners of railway assets.

\section{Acknowledgements}

The financial support provided by Australian Research Council (ARC) to conduct this research study is gratefully appreciated. The support provided by the University of Peradeniya, Sri Lanka by offering leave to conduct a doctoral study for the $1^{\text {st }}$ author is gratefully acknowledged. Constructive comments by Dr. Sanjay Nimbalkar and A/Prof. Cholachat Rujikiatkamjorn during the study is appreciated. The assistance provided by senior technical officers, namely Alan Grant, Cameron Neilson and Ritchie McLean in the School of Civil and Environmental Engineering, University of Wollongong is also appreciated.

\section{References}


Abadi, T., Le Pen, L., Zervos, A., and Powrie, W. (2015). "Measuring the area and number of ballast particle contacts at sleeper/ballast and ballast/subgrade interfaces." The International Journal of Railway Technology, 4(2), 45-72.

Alves Costa, P., Calçada, R., and Silva Cardoso, A. (2012). "Ballast mats for the reduction of railway traffic vibrations. Numerical study." Soil Dynamics and Earthquake Engineering, 42(0), 137-150.

Alves Ribeiro, C., Paixão, A., Fortunato, E., and Calçada, R. (2014). "Under sleeper pads in transition zones at railway underpasses: numerical modelling and experimental validation." Structure and Infrastructure Engineering, 11(11), 1432-1449.

AS 2758.7 (2015) "Aggregates and rock for engineering purposes, Part 7: Railway ballast." Standard Australia, Sydney, New South Wales, Australia.

ASTM D3999 (2003) "Standard Test Methods for the Determination of the Modulus and Damping Properties of Soils Using the Cyclic Triaxial Apparatus." ASTM International, West Conshohocken, PA.

Bi, Z., Sun, Q., Jin, F., and Zhang, M. (2011). "Numerical study on energy transformation in granular matter under biaxial compression." Granular Matter, 13(4), 503-510.

Bolton, M. D., Nakata, Y., and Cheng, Y. P. (2008). "Micro- and macro-mechanical behaviour of DEM crushable materials." Géotechnique, 58(6), 471-480.

Chrismer, S., and Davis, D. (2000). "Cost comparisons of remedial methods to correct track substructure instability." Transportation Research Record: Journal of the Transportation Research Board(1713), 10-14. 
DIN 45673-5 (2010) "Mechanical vibration - Resilient elements used in railway tracks - Part 5: Laboratory test procedures for under-ballast mats." the German Institute for Standardization, Berlin, Germany.

Einav, I. (2007). "Breakage mechanics—Part I: Theory." Journal of the Mechanics and Physics of Solids, 55(6), 1274-1297.

Esveld, C. (2001). Modern railway track, MRT-Production, Zaltbommel, The Netherlands.

Finegan, I. C., and Gibson, R. F. (1999). "Recent research on enhancement of damping in polymer composites." Composite Structures, 44(2-3), 89-98.

Hanson, C. E., and Singleton Jr, H. L. (2006). "Performance of ballast mats on passenger railroads: Measurement vs. projections." Journal of Sound and Vibration, 293(3-5), 873-877.

Hardin, B. O. (1985). "Crushing of Soil Particles." Journal of Geotechnical Engineering, 111(10), 1177-1192.

Hemsworth, B. (2000). "Reducing groundborne vibrations: state-of-the-art study." Journal of Sound and Vibration, 231(3), 703-709.

Hunt, G. (2005). "Review of the effect of track stiffness on track performance." RSSB, Research Project, 372.

Hussaini, S. K. K., Indraratna, B., and Vinod, J. (2012). "Performance of geosyntheticallyreinforced rail ballast in direct shear conditions." 11th Australia - New Zealand Conference on Geomechanics: Ground Engineering in a Changing World, Engineers Australia, Melbourne, Australia, 1268-1273.

Indraratna, B., Biabani, M., and Nimbalkar, S. (2015a). "Behavior of Geocell-Reinforced Subballast Subjected to Cyclic Loading in Plane-Strain Condition." Journal of Geotechnical and Geoenvironmental Engineering, 141(1), 1-16. 
Indraratna, B., Ionescu, D., and Christie, H. (1998). "Shear Behavior of Railway Ballast Based on Large-Scale Triaxial Tests." Journal of Geotechnical and Geoenvironmental Engineering, 124(5), 439-449.

Indraratna, B., Lackenby, J., and Christie, D. (2005). "Effect of confining pressure on the degradation of ballast under cyclic loading." Géotechnique, 55(4), 325-328.

Indraratna, B., Navaratnarajah, S. K., Nimbalkar, S., and Rujikiatkamjorn, C. (2014a). "Use of shock mats for enhanced stability of railroad track foundation." Australian Geomechanics Journal, Special Edition: ARC Centre of Excellence for Geotechnical Science and Engineering, 49(4), 101-111.

Indraratna, B., and Nimbalkar, S. (2013). "Stress-Strain Degradation Response of Railway Ballast Stabilized with Geosynthetics." Journal of Geotechnical and Geoenvironmental Engineering, 139(5), 684-700.

Indraratna, B., Nimbalkar, S., Christie, D., Rujikiatkamjorn, C., and Vinod, J. (2010). "Field Assessment of the Performance of a Ballasted Rail Track with and without Geosynthetics." Journal of Geotechnical and Geoenvironmental Engineering, 136(7), 907-917.

Indraratna, B., Nimbalkar, S., and Neville, T. (2014b). "Performance assessment of reinforced ballasted rail track." Proceedings of the ICE-Ground Improvement, 167(1), 24-34.

Indraratna, B., and Salim, W. (2002). "Modelling of particle breakage of coarse aggregates incorporating strength and dilatancy." Geotechnical Engineering, 155(4), 243-252.

Indraratna, B., Salim, W., and Rujikiatkamjorn, C. (2011). Advanced Rail Geotechnology: Ballasted Track, CRC Press/Balkema, Rotterdam, Netherlands. 
Indraratna, B., Sun, Q. D., and Nimbalkar, S. (2015b). "Observed and predicted behaviour of rail ballast under monotonic loading capturing particle breakage." Canadian Geotechnical Journal, 52(1), 73-86.

Indraratna, B., Vinod, J. S., and Lackenby, J. (2009). "Influence of particle breakage on the resilient modulus of railway ballast." Géotechnique, 59(7), 643-646.

Ishikawa, T., Sekine, E., and Miura, S. (2011). "Cyclic deformation of granular material subjected to moving-wheel loads." Canadian Geotechnical Journal, 48(5), 691-703.

Jeffs, T., and Tew, G. (1991). "A Review of Track Design Procedures, Vol. 2 - Sleepers and Ballast." Railways of Australia, Melbourne, Australia.

Johansson, A., Nielsen, J. C. O., Bolmsvik, R., Karlström, A., and Lundén, R. (2008). "Under sleeper pads-Influence on dynamic train-track interaction." Wear, 265(9-10), 1479-1487.

Kaewunruen, S. (2007). "Experimental and numerical studies for evaluating dynamic behaviour of prestressed concrete sleepers subject to severe impact loading."Ph.D. Thesis, University of Wollongong, Wollongong, Australia.

Kempfert, H., and Hu, Y. (1999). "Measured dynamic loading of railway underground." Proc., 11th Pan-American Conf. on Soil Mechanics and Geotechnical Engineering, International Society of Soil Mechanics and Geotechnical Engineering, Fozdo Iguacu, Brazil, 843-847.

Lackenby, J., Indraratna, B., McDowell, G., and Christie, D. (2007). "Effect of confining pressure on ballast degradation and deformation under cyclic triaxial loading." Géotechnique, 57(6), 527-536.

Lade, P. V., Yamamuro, J. A., and Bopp, P. A. (1996). "Significance of Particle Crushing in Granular Materials." Journal of Geotechnical Engineering, 122(4), 309-316. 
Le, R., Ripke, B., and Zacher, M. (1999). "Ballast mats on high speed bridges." Proc., Fourth European Conference on Structural Dynamics: EURODYN'99, A.A. Balkema, Rotterdam, 699-703.

Li, D., and Davis, D. (2005). "Transition of Railroad Bridge Approaches." Journal of Geotechnical and Geoenvironmental Engineering, 131(11), 1392-1398.

Li, D., Hyslip, J. P., Sussmann, T. R., and Chrismer, S. M. (2015). Railway geotechnics, CRC Press/Taylor \& Francis Group, Boca Raton, FL, USA.

Li, D., and Selig, E. (1998a). "Method for Railroad Track Foundation Design. I: Development." Journal of Geotechnical and Geoenvironmental Engineering, 124(4), 316-322.

Li, D., and Selig, E. (1998b). "Method for Railroad Track Foundation Design. II: Applications." Journal of Geotechnical and Geoenvironmental Engineering, 124(4), 323-329.

Liu, M., Gao, Y., and Liu, H. (2014). "An elastoplastic constitutive model for rockfills incorporating energy dissipation of nonlinear friction and particle breakage." Int. J. Numer. Anal. Meth. Geomech., 38(9), 935-960.

Lombaert, G., Degrande, G., Vanhauwere, B., Vandeborght, B., and François, S. (2006). "The control of ground-borne vibrations from railway traffic by means of continuous floating slabs." Journal of Sound and Vibration, 297(3-5), 946-961.

Marsal, R. J. (1967). "Large-scale testing of rockfill materials." Journal of the Soil Mechanics and Foundations Engineering, ASCE, 93(2), 27-43.

Marschnig, S., and Veit, P. (2011). "Making a Case For Under-Sleeper Pads." International Railway Journal, 51(1), 27-29. 
Müller, R. (2008). "Mitigation Measures for Open Lines against Vibration and Ground-Borne Noise: A Swiss Overview." Noise and Vibration Mitigation for Rail Transportation Systems, Springer Berlin Heidelberg, 264-270.

Nimbalkar, S., and Indraratna, B. (2016). "Improved Performance of Ballasted Rail Track Using Geosynthetics and Rubber Shockmat." Journal of Geotechnical and Geoenvironmental Engineering, 142(8), 04016031.

Nimbalkar, S., Indraratna, B., Dash, S., and Christie, D. (2012). "Improved Performance of Railway Ballast under Impact Loads Using Shock Mats." Journal of Geotechnical and Geoenvironmental Engineering, 138(3), 281-294.

Read, D., and Li, D. (2006). "Design of Track Transitions: TCRP Research Results Digest 79." Transportation Research Board of the National Academies, The National Academies Press, Washington, DC.

Selig, E. T., and Waters, J. M. (1994). Track Geotechnology and Substructure Management, Thomas Telford, London.

Sitharam, T. G., and Vinod, J. S. (2010). "Evaluation of Shear Modulus and Damping Ratio of Granular Materials Using Discrete Element Approach." Geotechnical and Geological Engineering, 28(5), 591-601.

Sol-Sanchez, M., Moreno-Navarro, F., and Rubio-Gámez, M. C. (2015). "The use of elastic elements in railway tracks: A state of the art review." Construction and Building Materials, 75(0), 293-305.

Sun, Q. D., Indraratna, B., and Nimbalkar, S. (2016). "Deformation and Degradation Mechanisms of Railway Ballast under High Frequency Cyclic Loading." Journal of Geotechnical and Geoenvironmental Engineering, 142(1), 1-12. 
Thakur, P. K. (2011). "Cyclic densification of ballast and associated deformation and degradation."Ph.D. Thesis, University of Wollongong.

Timoshenko, S., and Goodier, J. N. (1970). Theory of Elasticity, McGraw-Hill Singapore.

Ueng, T.-S., and Chen, T.-J. (2000). "Energy aspects of particle breakage in drained shear of sands." Géotechnique, 50(1), 65-72.

Vesic, A. S., and Clough, G. W. (1968). "Behavior of granular materials under high stresses." Journal of the Soil Mechanics and Foundations Engineering, ASCE, 94(SM3), 661-688.

Wang, J., and Yan, H. (2012). "DEM analysis of energy dissipation in crushable soils." Soils and Foundations, 52(4), 644-657.

Wettschureck, R. (1997). "Measures to reduce structure-borne noise emissions induced by above-ground, open railway lines." Rail Engineering International, 26(1), 12-16.

Yang, L., Powrie, W., and Priest, J. (2009). "Dynamic Stress Analysis of a Ballasted Railway Track Bed during Train Passage." Journal of Geotechnical and Geoenvironmental Engineering, 135(5), 680-689. 
Table 1. Mechanical Properties of Rubber Mat

\begin{tabular}{lll}
\hline \multicolumn{1}{c}{ Material properties } & Value & Unit \\
\hline Thickness & 10 & $\mathrm{~mm}$ \\
Weight (per unit area) & 9.2 & $\mathrm{~kg} / \mathrm{m}^{2}$ \\
Young's Modulus & 6.12 & $\mathrm{MPa}$ \\
Tensile Strength & 600 & $\mathrm{kPa}$ \\
Tensile Strain at Failure & 80 & $\%$ \\
Static Stiffness, $C_{\text {stat }}$ (DIN 45673-5) & 0.20 & $\mathrm{~N} / \mathrm{mm}^{3}$ \\
Dynamic Stiffness, $C_{\text {dyn1 }}(5-30 \mathrm{~Hz})($ DIN 45673-5) & $0.46-0.59$ & $\mathrm{~N} / \mathrm{mm}^{3}$ \\
\hline
\end{tabular}

Table 2. Summary of Large-Scale Laboratory Tests using PSPTA

\begin{tabular}{|c|c|c|c|}
\hline $\begin{array}{c}\text { Axle } \\
\text { Load }\end{array}$ & Test No. & $\begin{array}{c}\text { Frequency } \\
\text { (Hz) }\end{array}$ & $\begin{array}{c}\text { Rubber Mat } \\
\text { Used } \\
\text { (Yes/No) }\end{array}$ \\
\hline 25-ton & 1 & 15 & No \\
\cline { 2 - 4 } & 2 & 15 & Yes \\
\cline { 2 - 4 } & 3 & 20 & No \\
\cline { 2 - 4 } & 4 & 20 & Yes \\
\cline { 2 - 4 } & 5 & 25 & No \\
\cline { 2 - 4 } & 6 & 25 & Yes \\
\hline 35-ton & 7 & 10 & No \\
\cline { 2 - 4 } & 8 & 10 & Yes \\
\cline { 2 - 4 } & 9 & 15 & No \\
\cline { 2 - 4 } & 10 & 15 & Yes \\
\cline { 2 - 4 } & 11 & 20 & No \\
\cline { 2 - 4 } & 12 & 20 & Yes \\
\hline
\end{tabular}




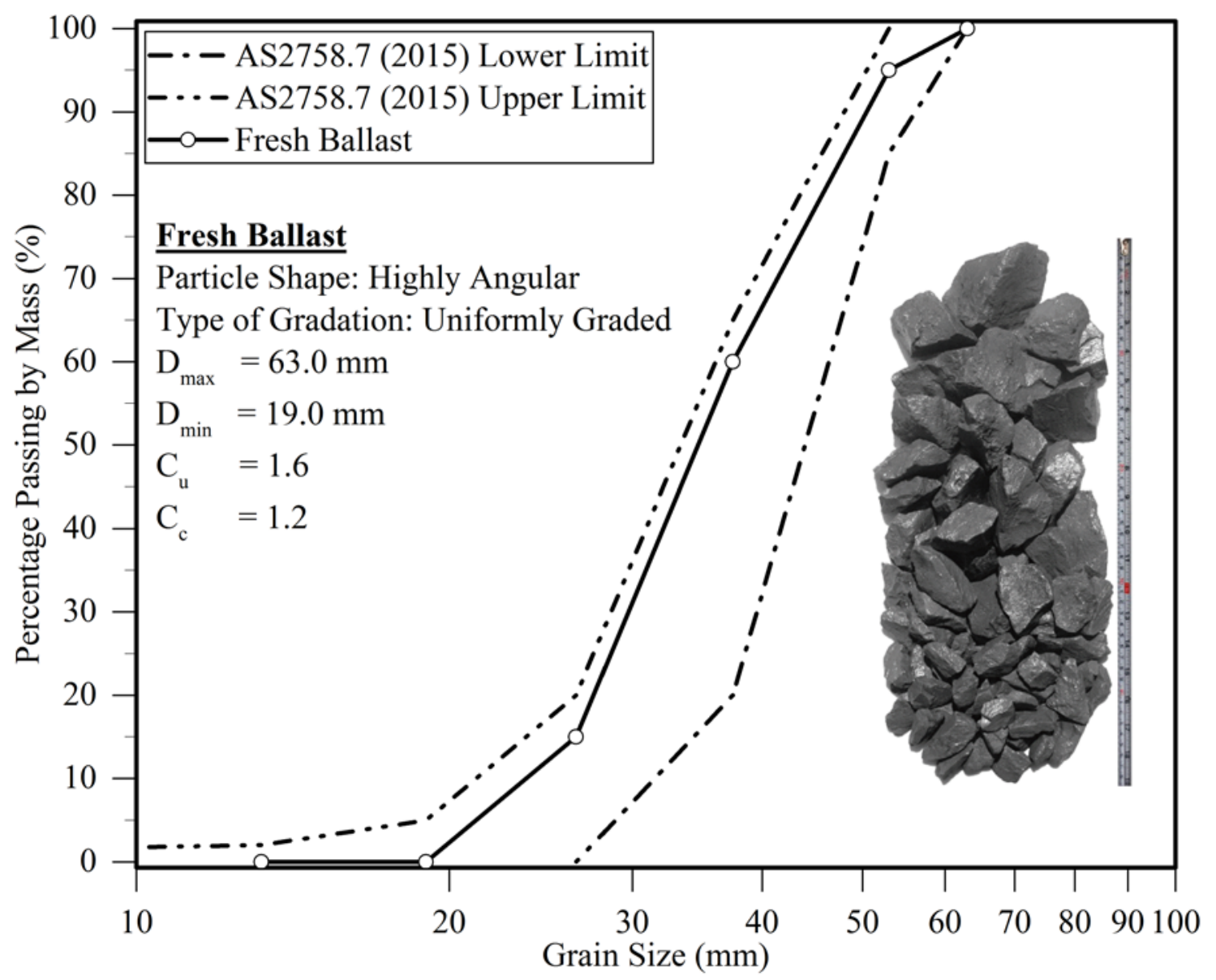

Fig. 1. Particle Size Distribution (PSD) of Ballast 


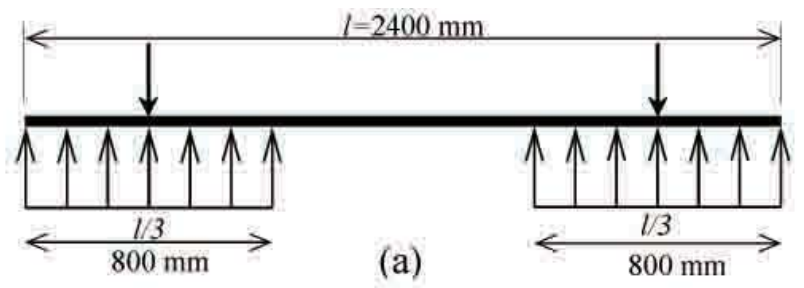

(a)
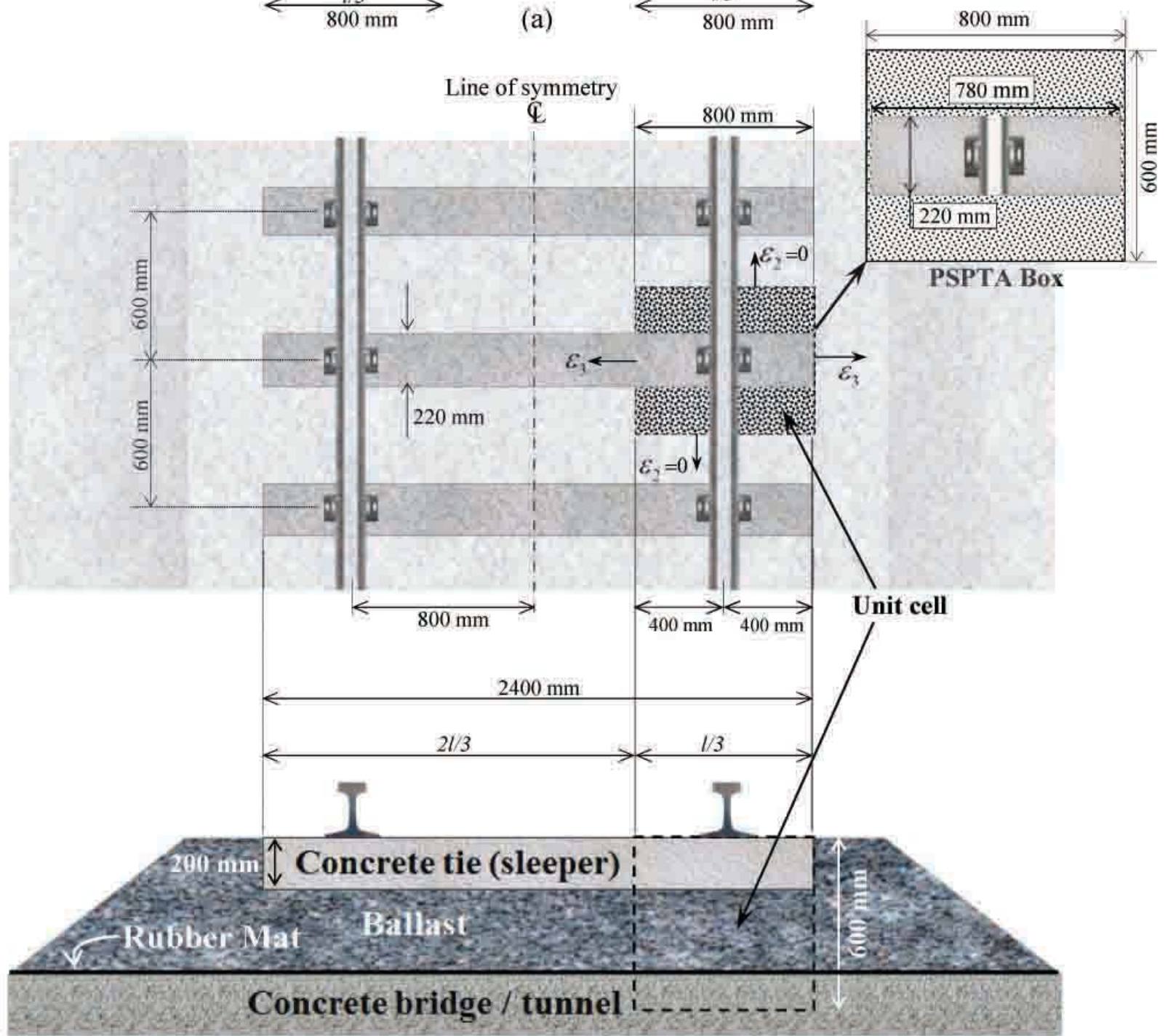

(b)

Fig. 2. (a) Simplified track geometry for assessing the tie-ballast contact pressure (modified from (Jeffs and Tew 1991); (b) typical arrangement of the hard base track substructure simulated in the PSPTA Box (modified from Indraratna et al. (2015a) 


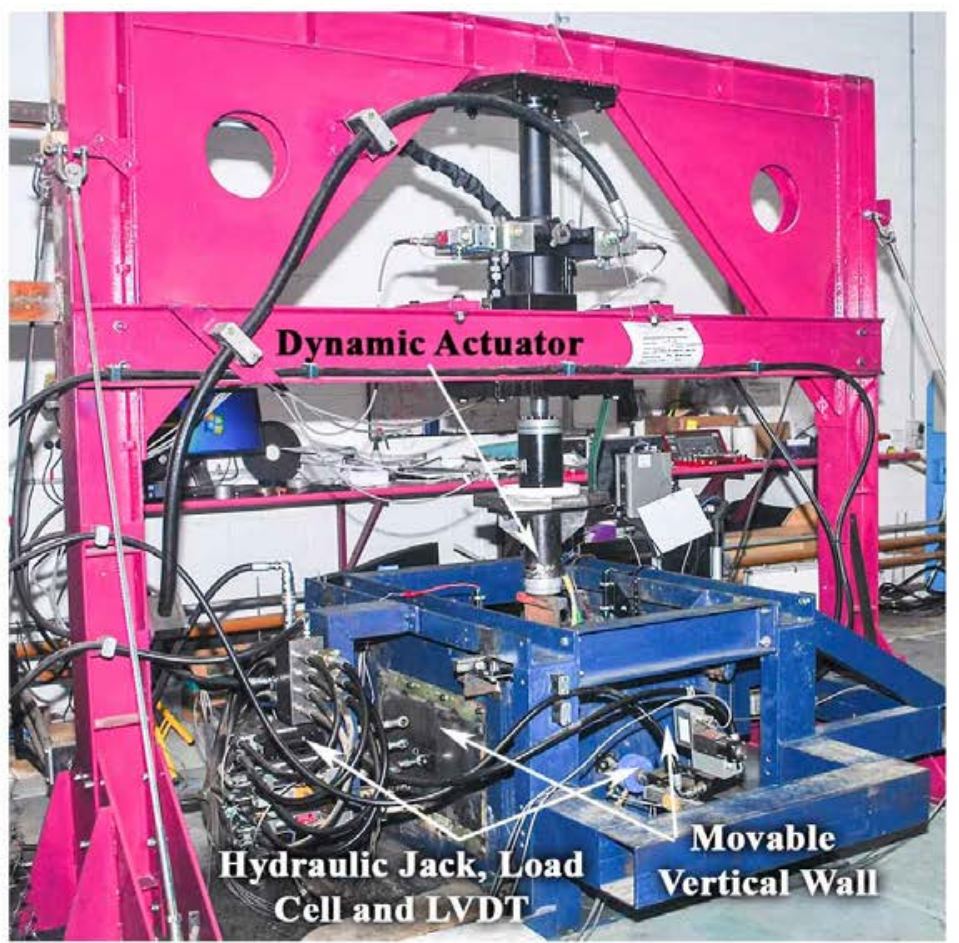

(a)

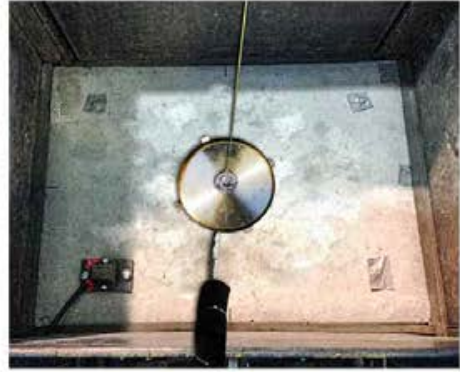

(e)

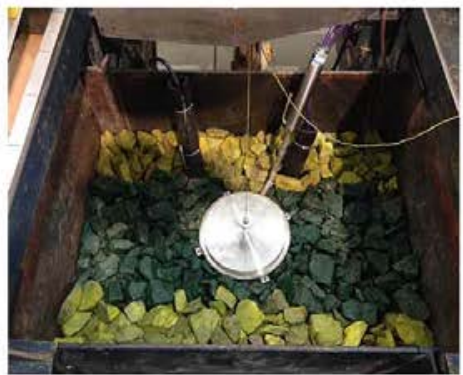

(h)

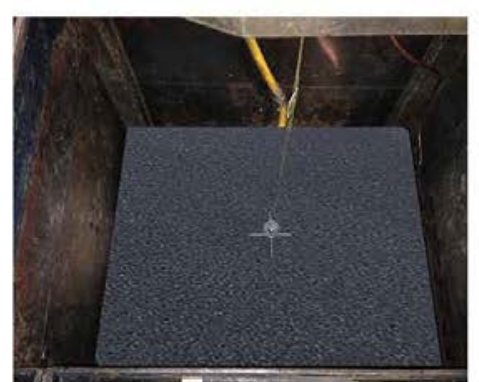

(f)

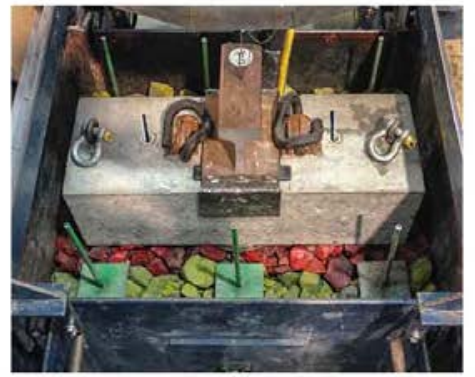

(i)

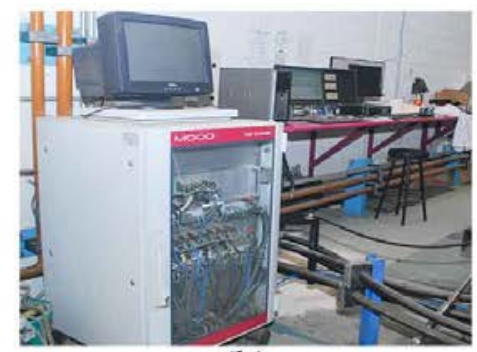

(b)

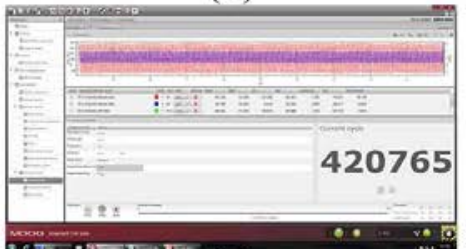

(c)

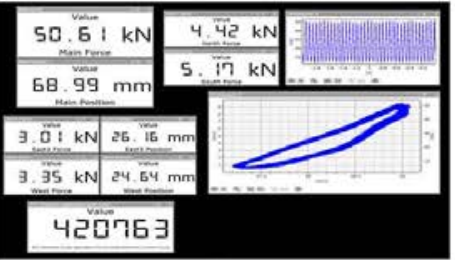

(d)

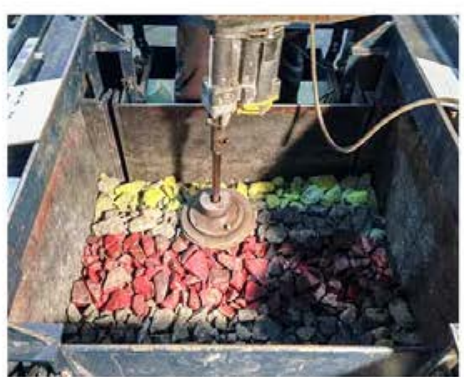

(g)

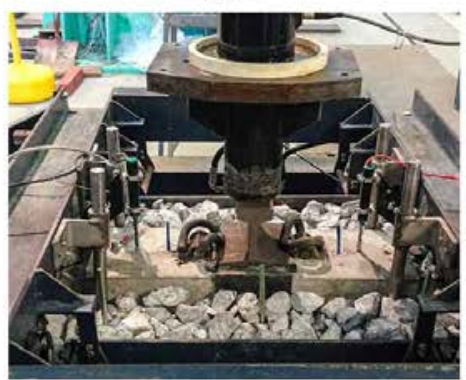

(j)

Fig. 3. (a) Process simulation prismoidal triaxial apparatus; (b) data acquisition unit; (c) load and frequency controller software module; (d) digital data output from the controller; (e) concrete base and pressure cell at the bottom of the triaxial cell; (f) rubber mat placed on top of a concrete base; (g) compaction of ballast layer using a rubber padded vibratory hammer; (h) pressure cell placed at the middle layer; (i) rail-concrete tie (sleeper) assembly placed on top of ballast layer and pressure cell placed at the tie-ballast interface; (j) top view of final test arrangements with settlement plates, potentiometer and servo-hydraulic actuator. 


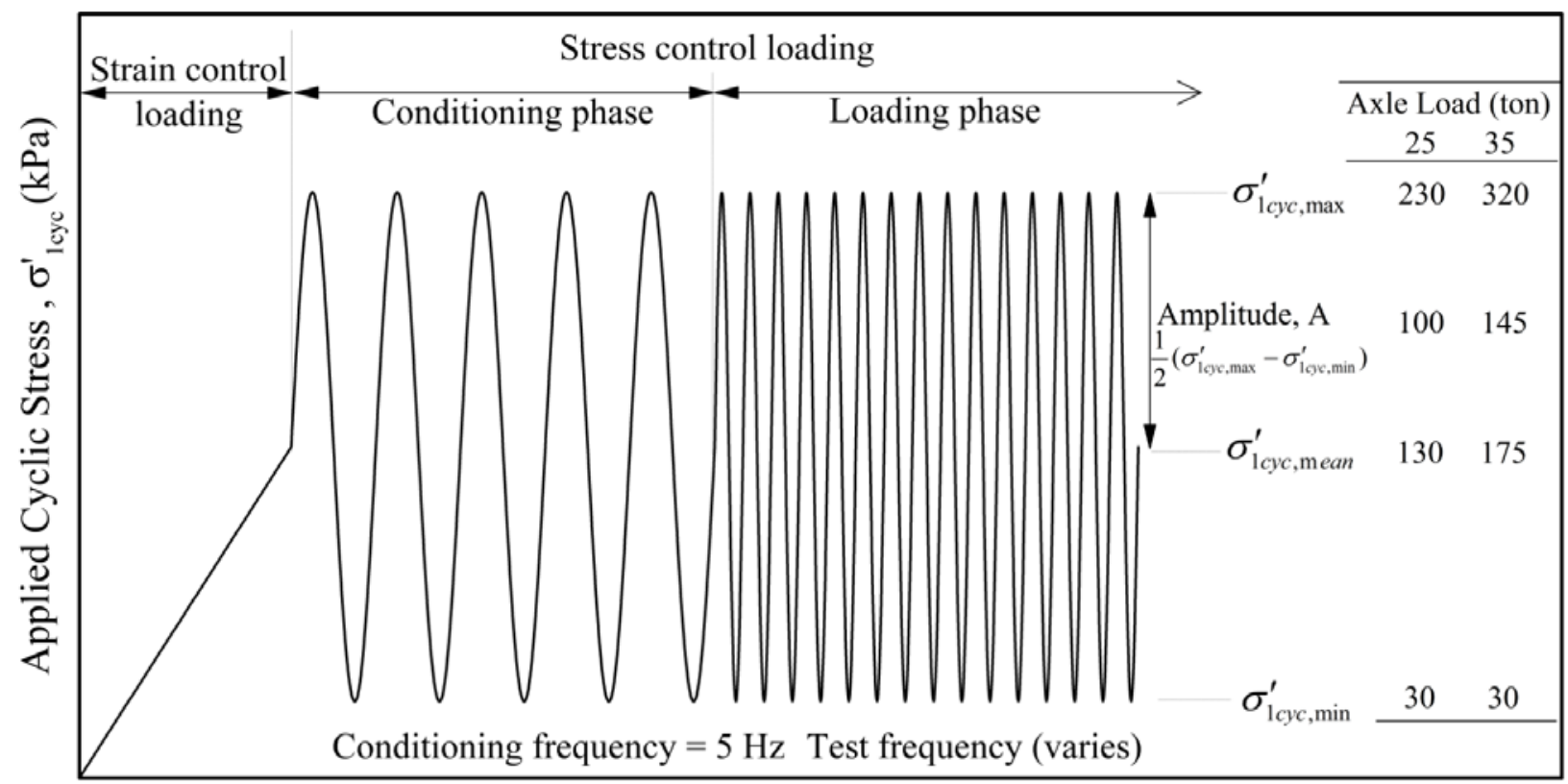

Time, $\mathrm{t}(\mathrm{sec})$

Fig. 4. Typical applied cyclic load 
Number of Cycles, $\mathrm{N}$

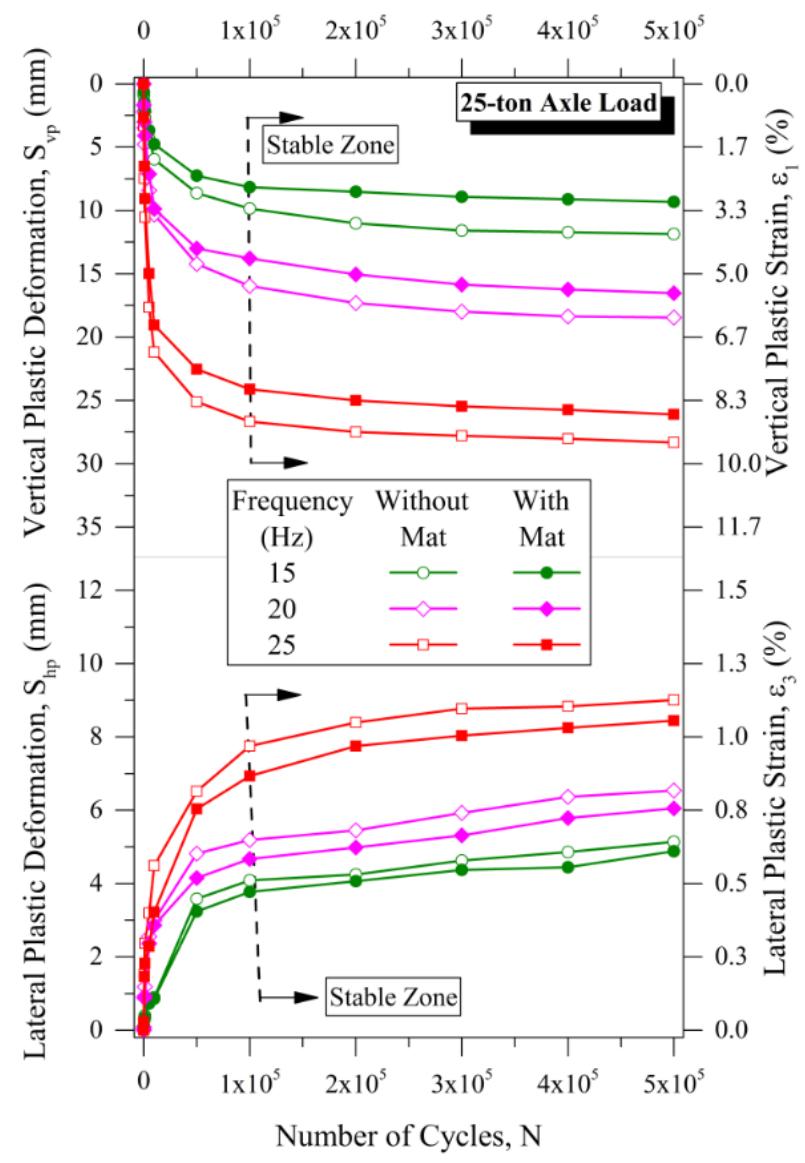

(a)
Number of Cycles, $\mathrm{N}$

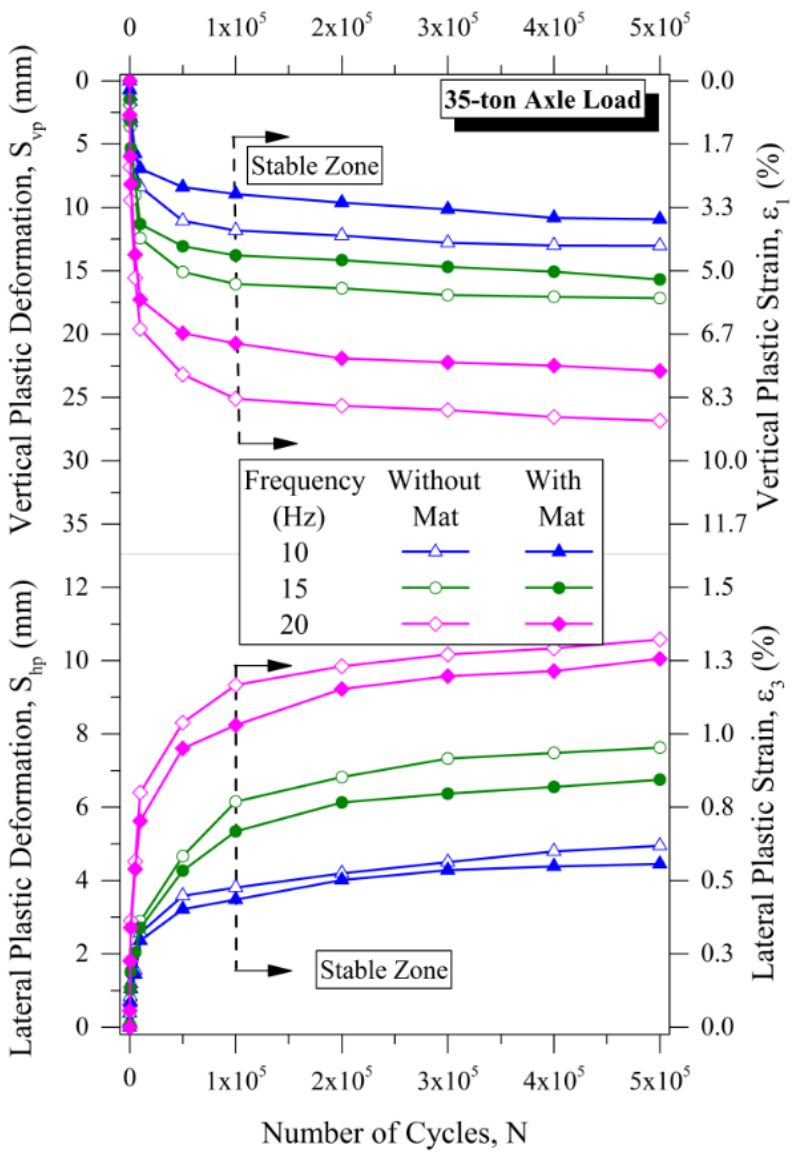

(b)

Fig. 5. Variation of vertical and lateral plastic deformation with number of cycles $(N)$ : (a) 25-ton; and (b) 35-ton axle loads 
Number of Cycles, $\mathrm{N}$

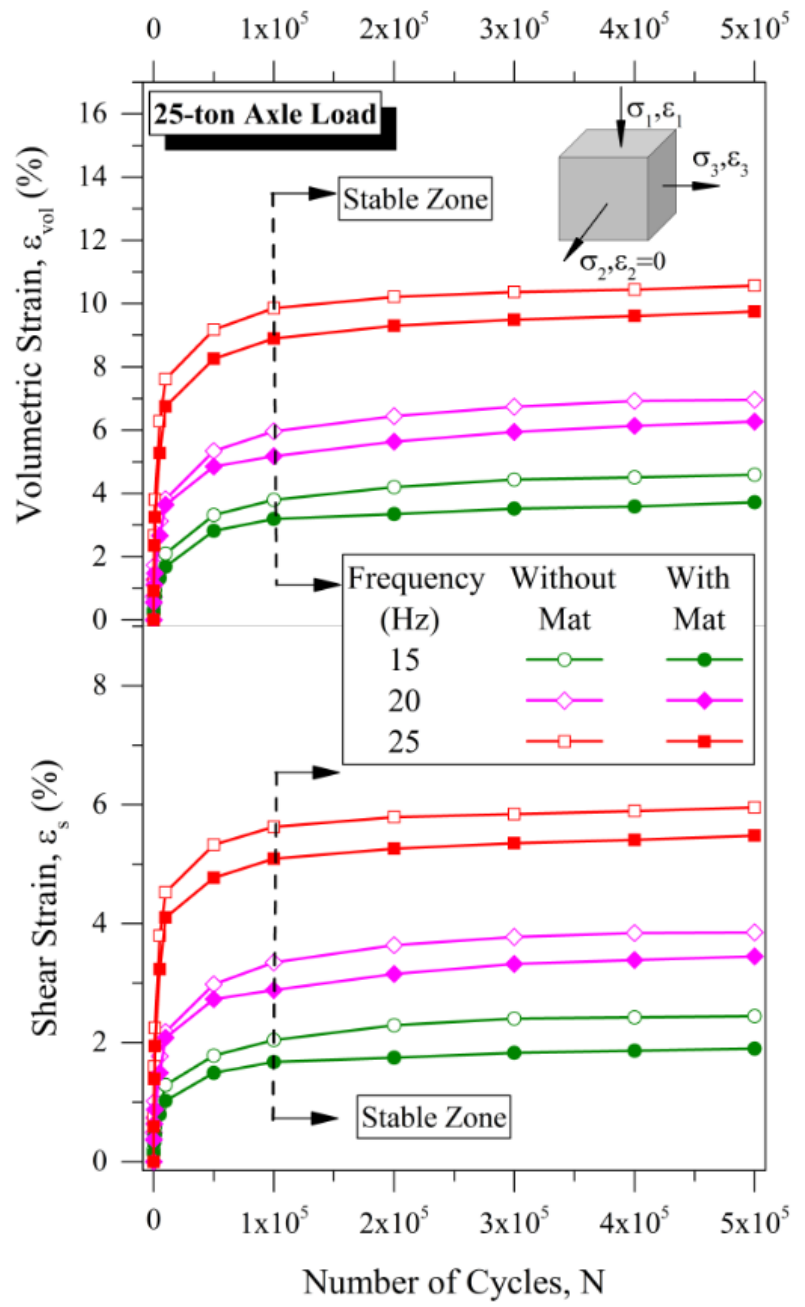

(a)
Number of Cycles, $\mathrm{N}$

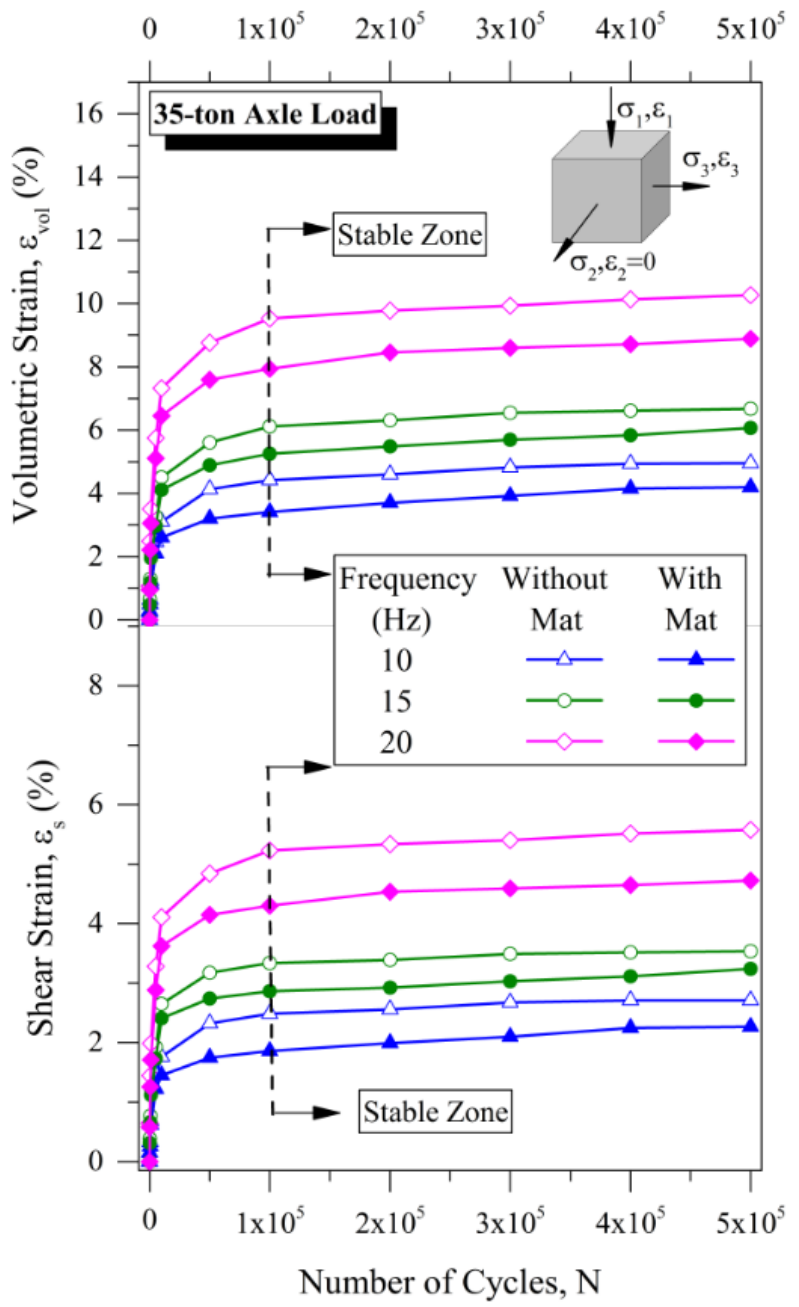

(b)

Fig. 6. Variation of volumetric and shear strain with number of cycles $(N)$ : (a) 25-ton; and (b) 35-ton axle loads 


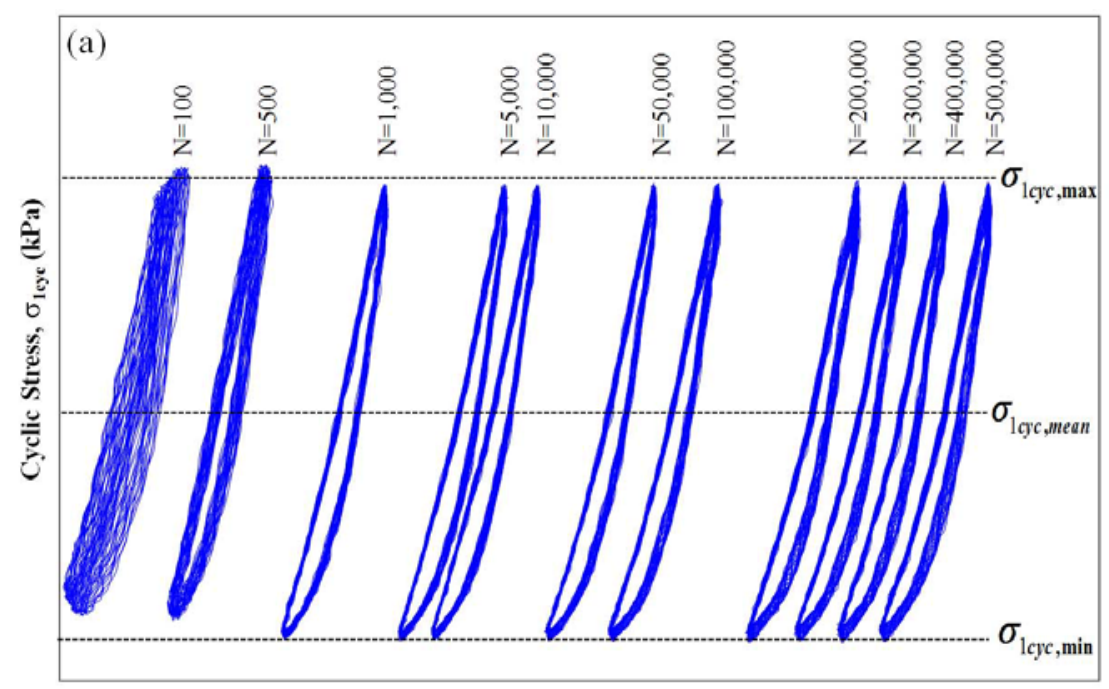

Strain, $\varepsilon$

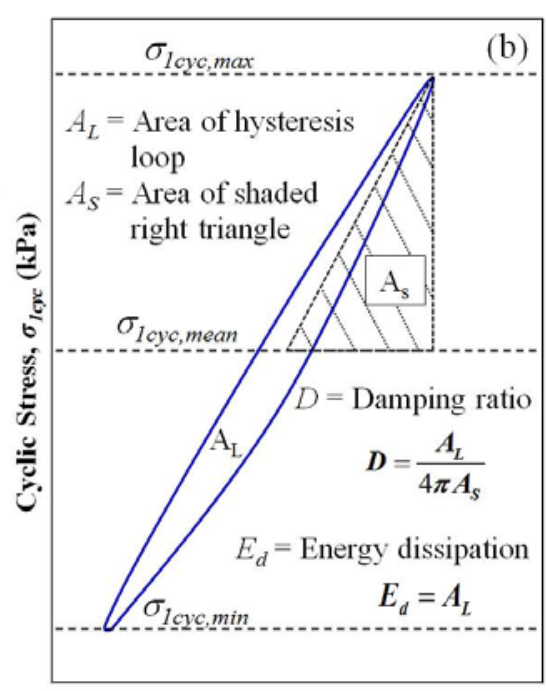

Strain, $\varepsilon$

Fig. 7. (a) Typical stress-strain hysteresis loop from cyclic load test; and (b) Schematic of typical hysteresis loop shows Damping Ratio $(D)$ and Energy Dissipation $\left(E_{d}\right)$ 


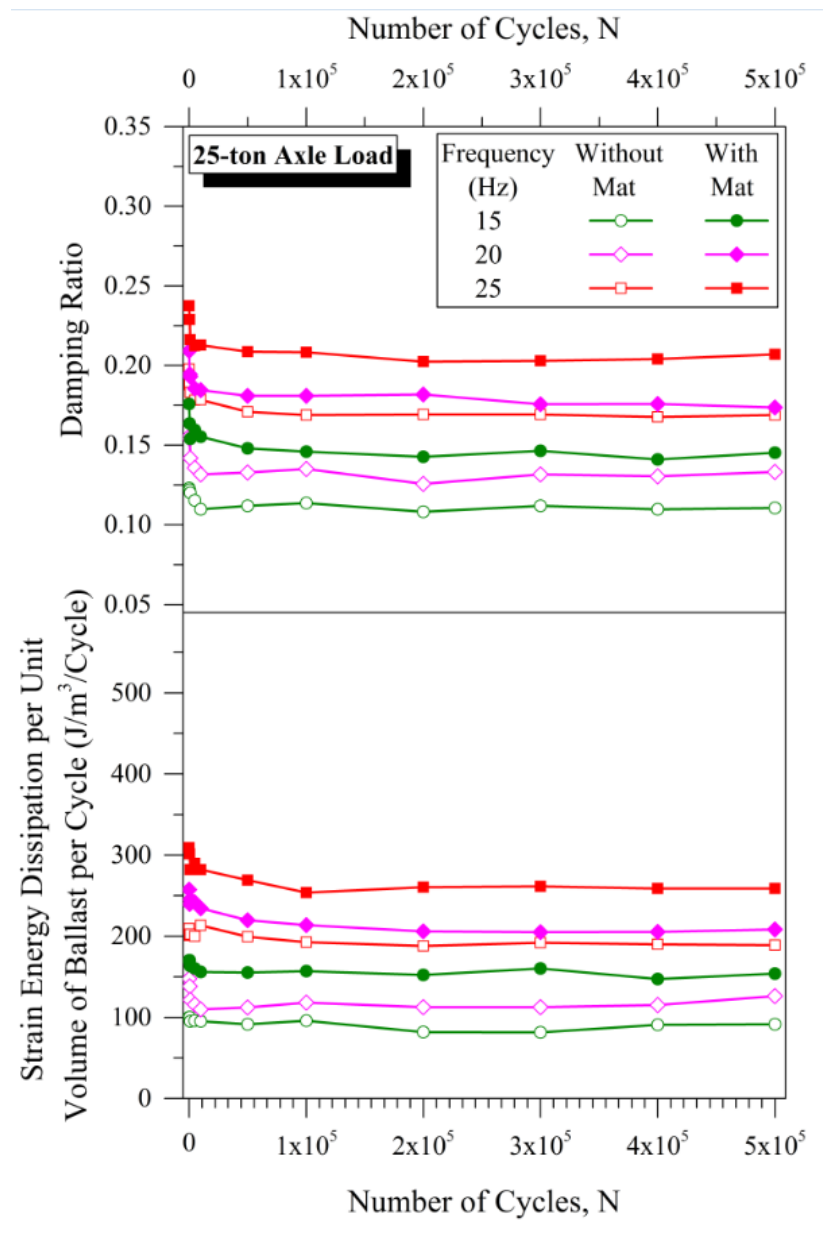

(a)

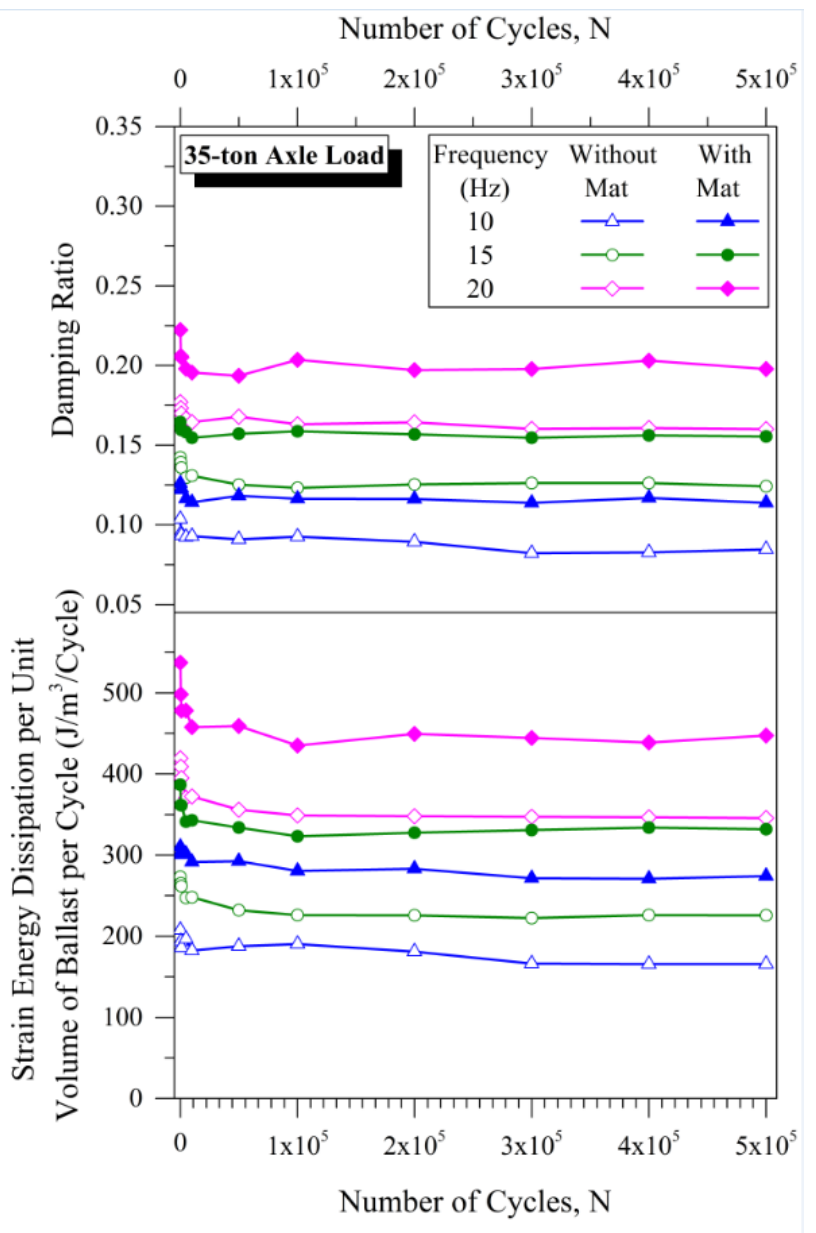

(b)

Fig. 8. Variation of Damping Ratio and Strain Energy Dissipation with number of cycles ( $N)$ : (a) 25-ton; and (b) 35-ton axle loads 


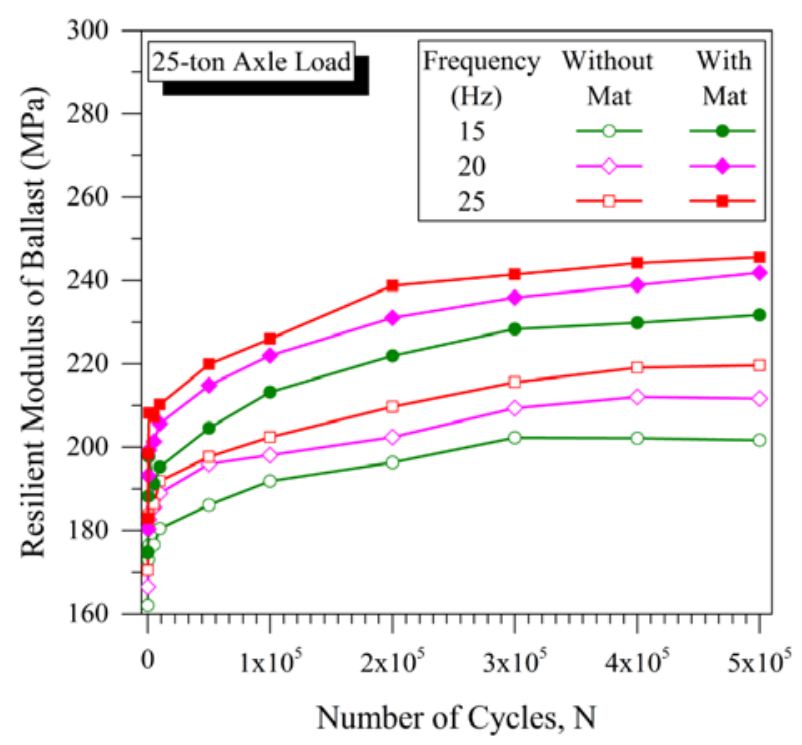

(a)

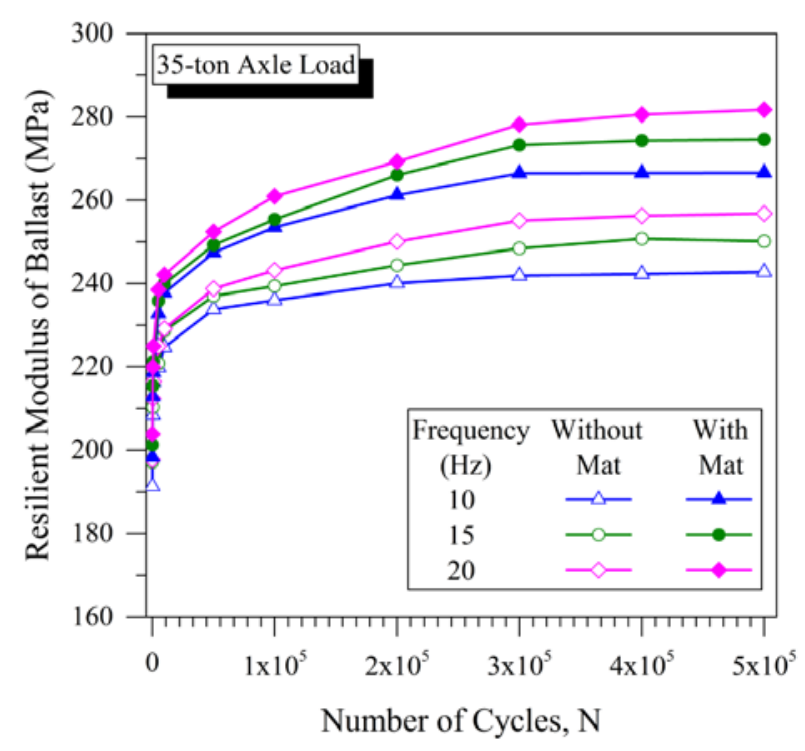

(b)

Fig. 9. Variation of Resilient Modulus of Ballast with number of cycles ( $N$ ): (a) 25-ton; and (b) 35-ton axle loads

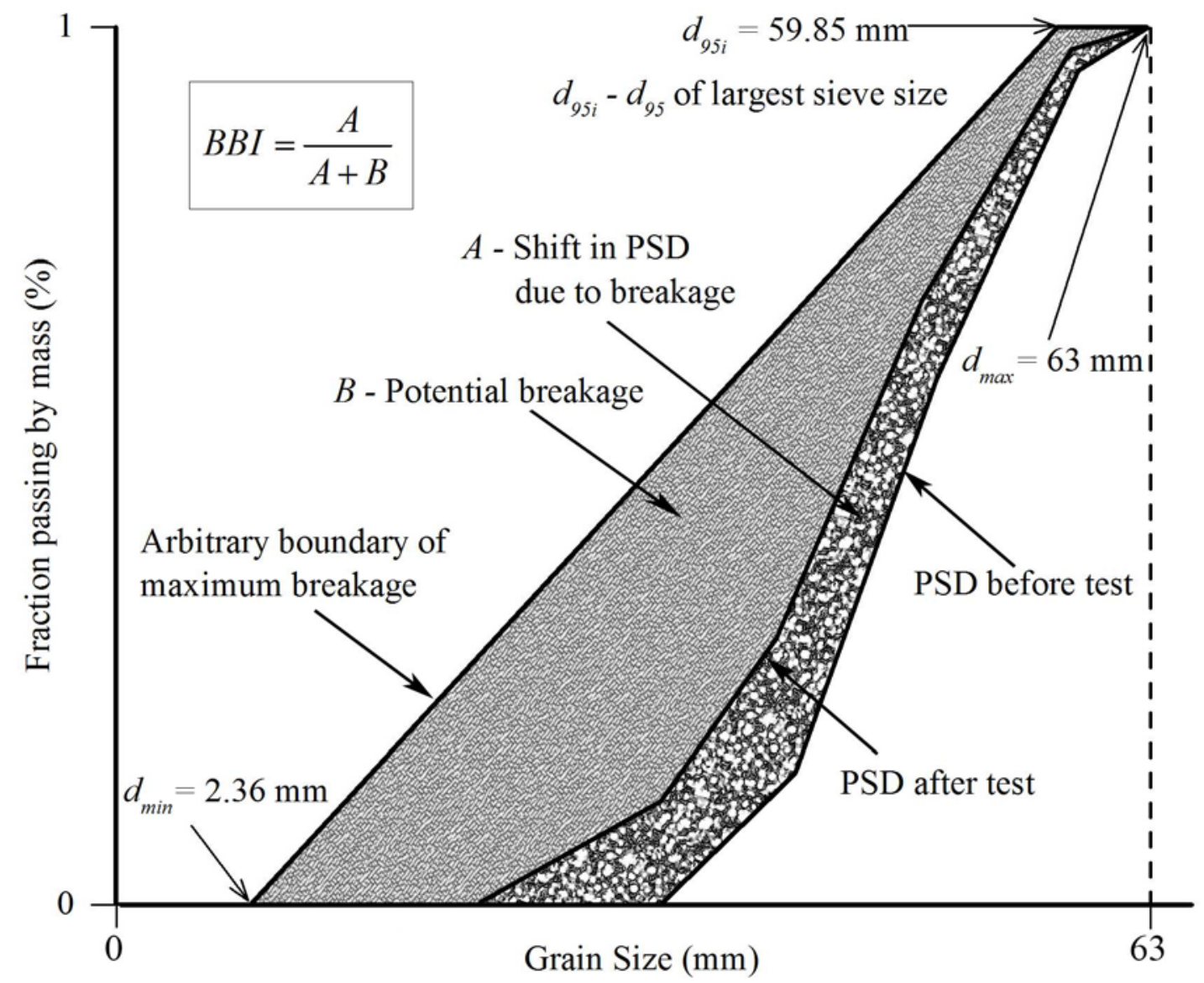

Fig. 10. Method to calculate Ballast Breakage Index, BBI (data from Indraratna et al. (2005)) 


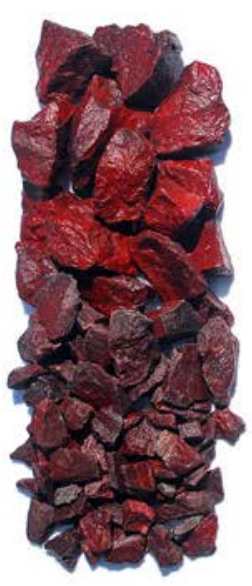

(a) Fresh Ballast

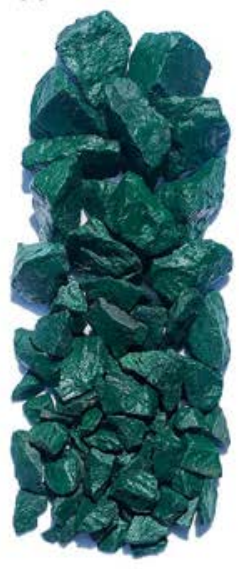

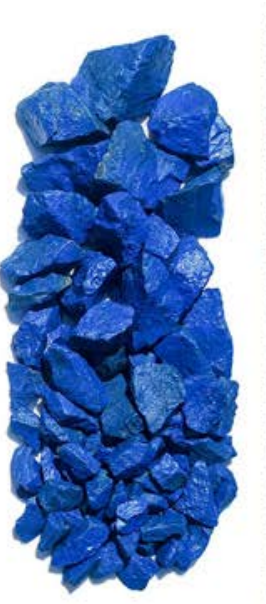

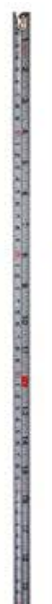

(b) Degraded Ballast

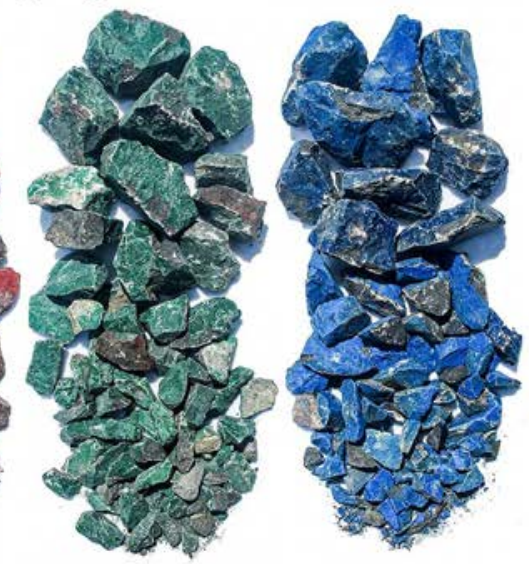

Fig. 11. Photographs showing color coded ballast from top, middle and bottom layers: (a) Fresh ballast before test; (b) Degraded ballast after test (Test No. 3)

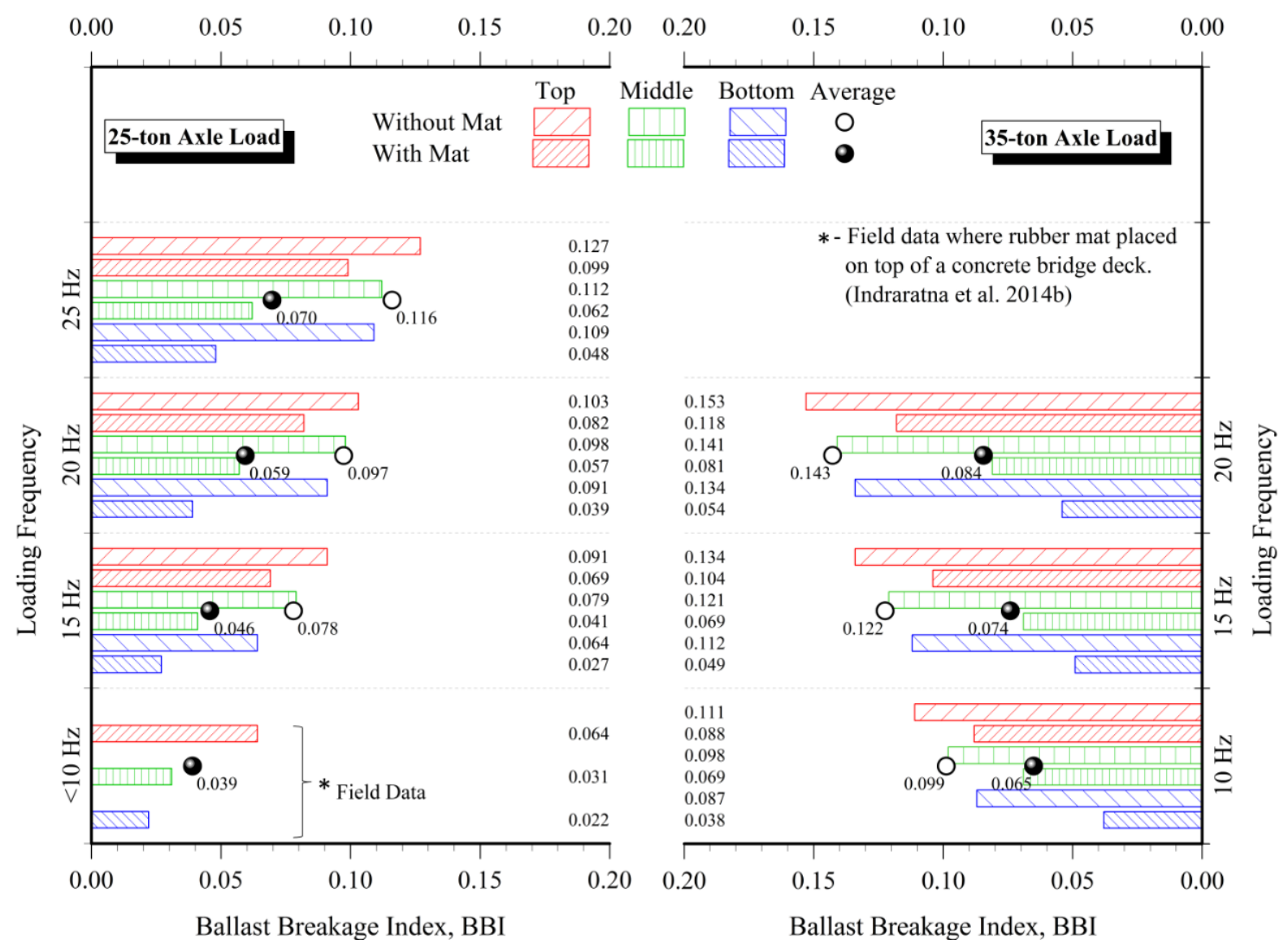

Fig. 12. Variation of Ballast Breakage Index (BBI) 


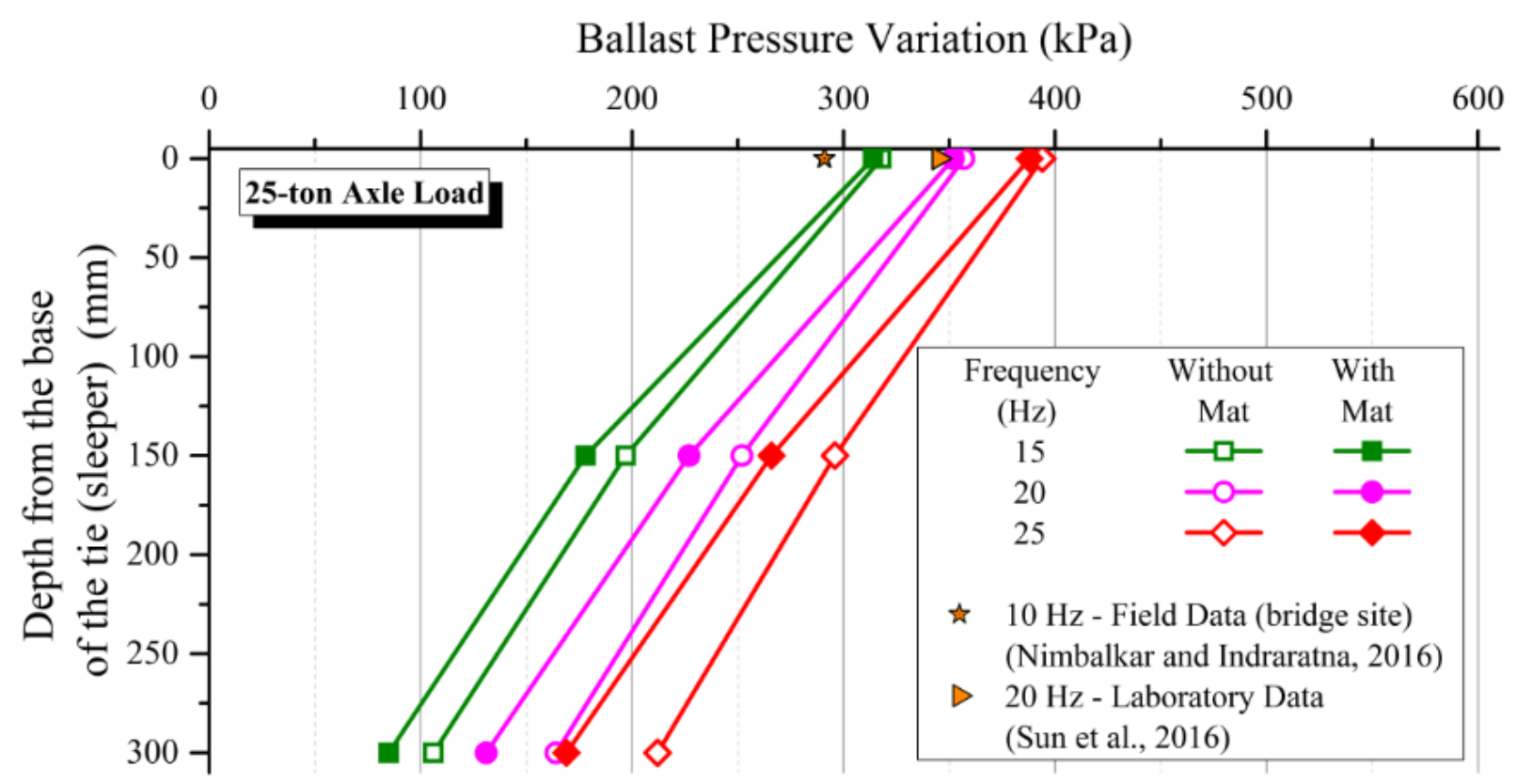

(a)

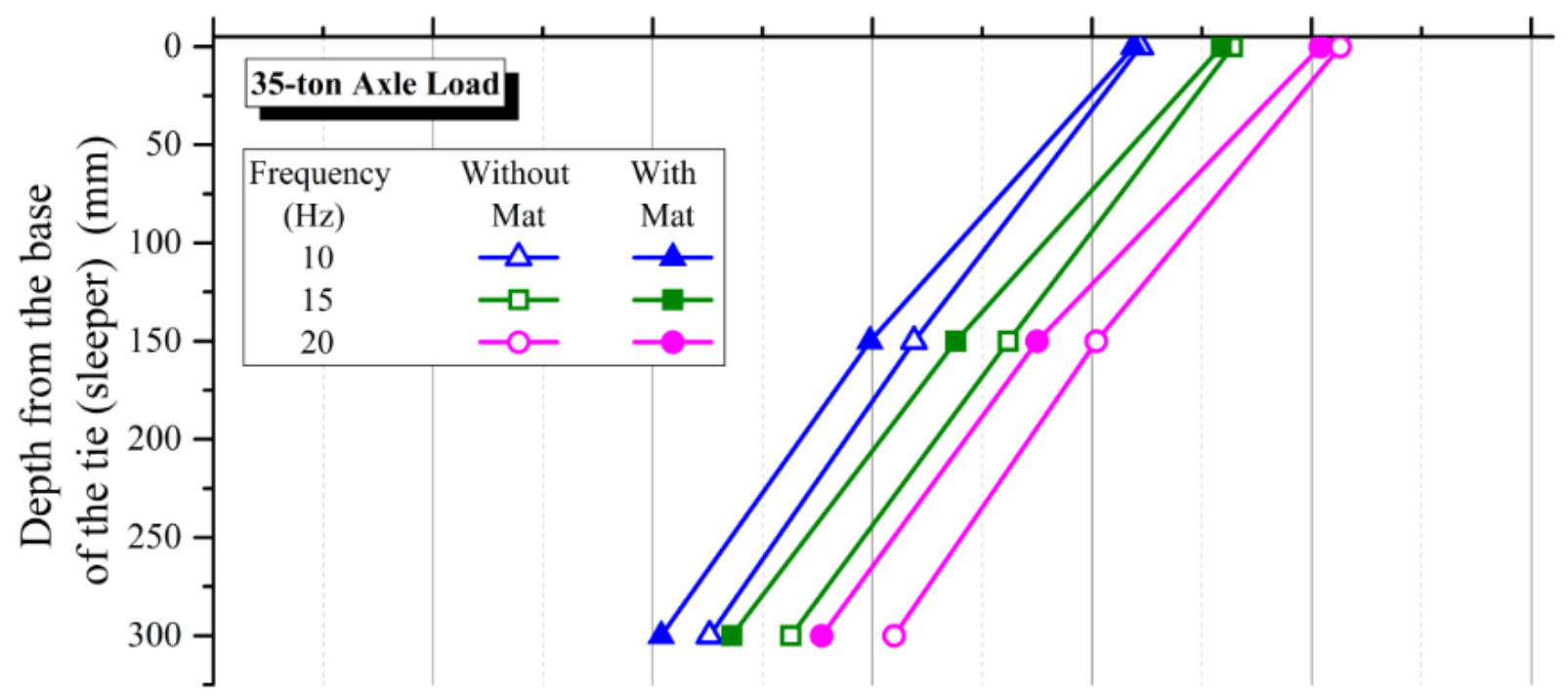

(b)

Fig. 13. Ballast pressure variation: (a) 25-ton axle load; and (b) 35-ton axle load 


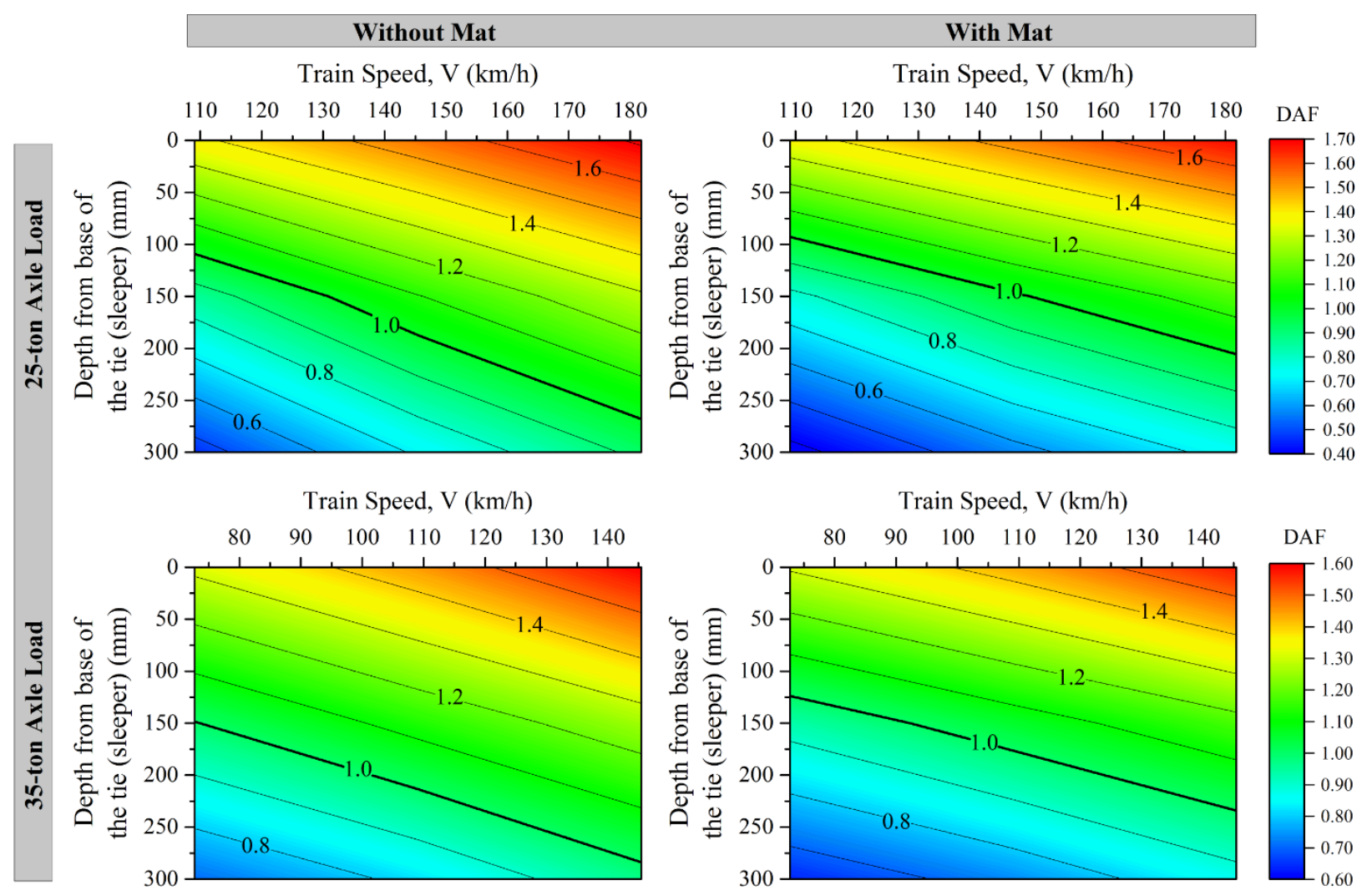

Fig. 14. Variation of DAF within the ballast mass for varying train speeds 


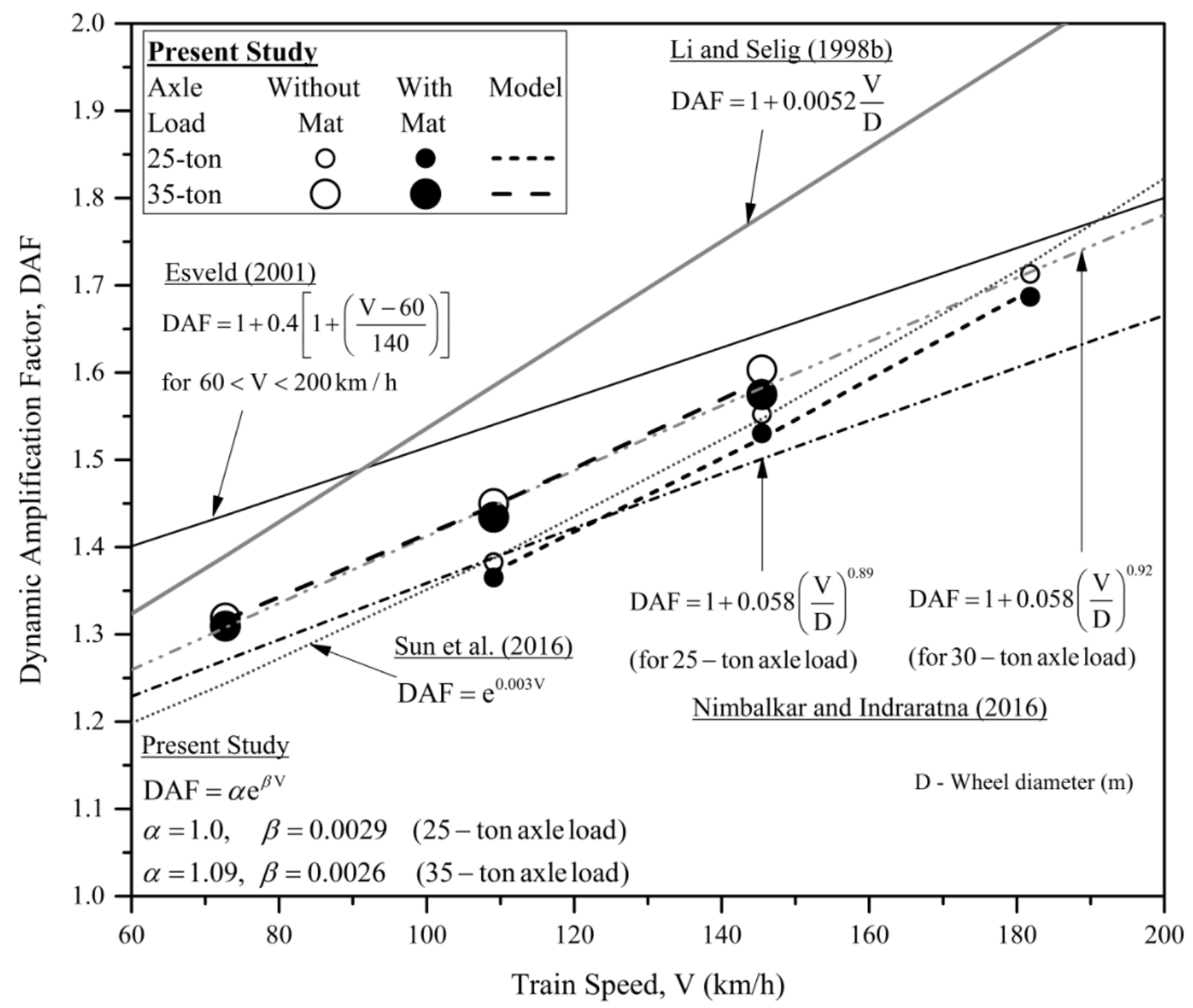

Fig. 15. Variation of dynamic amplification factor (DAF) with train speed (V) 


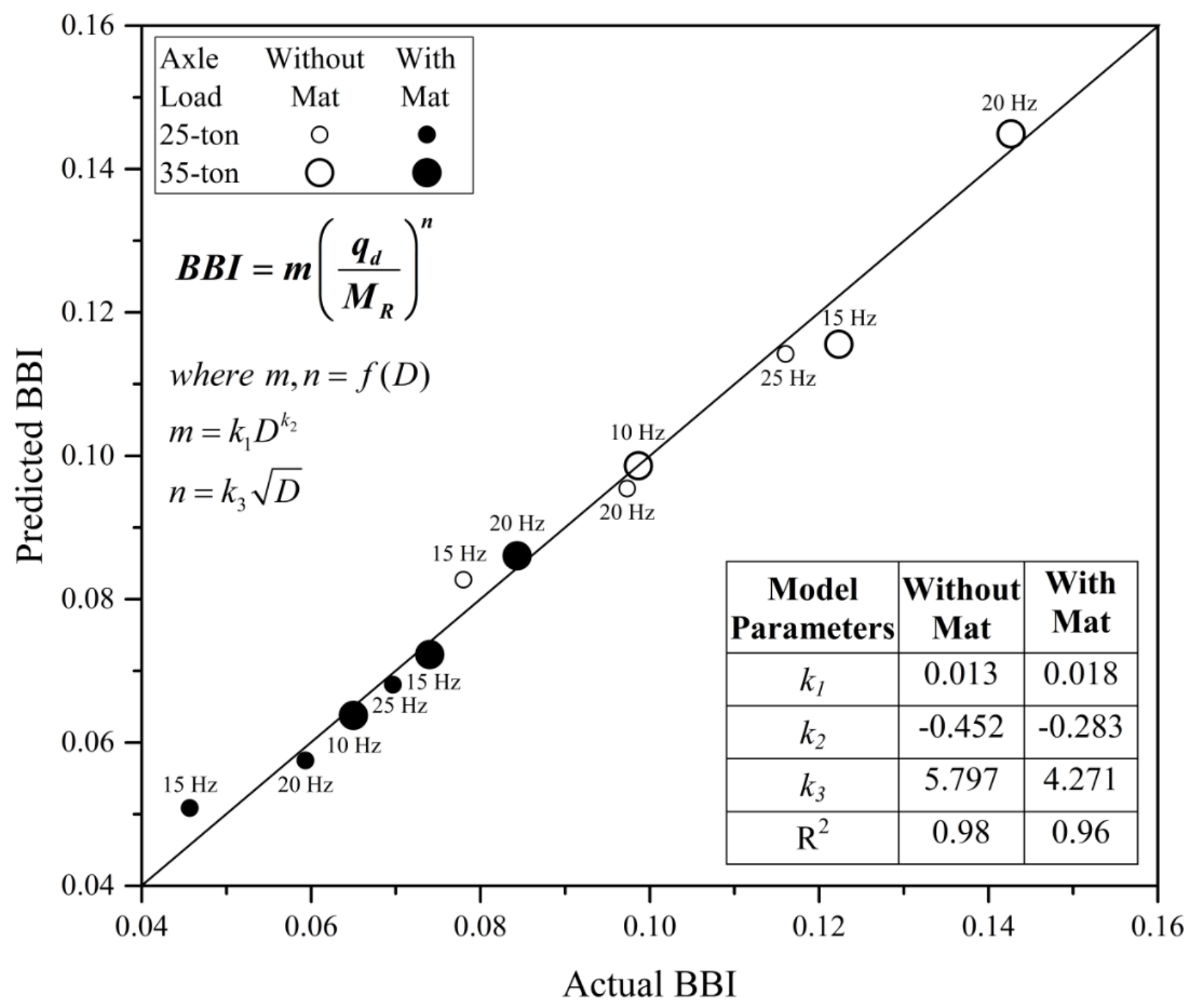

Fig. 16. Predicted and actual values of ballast breakage index $(B B I)$ 


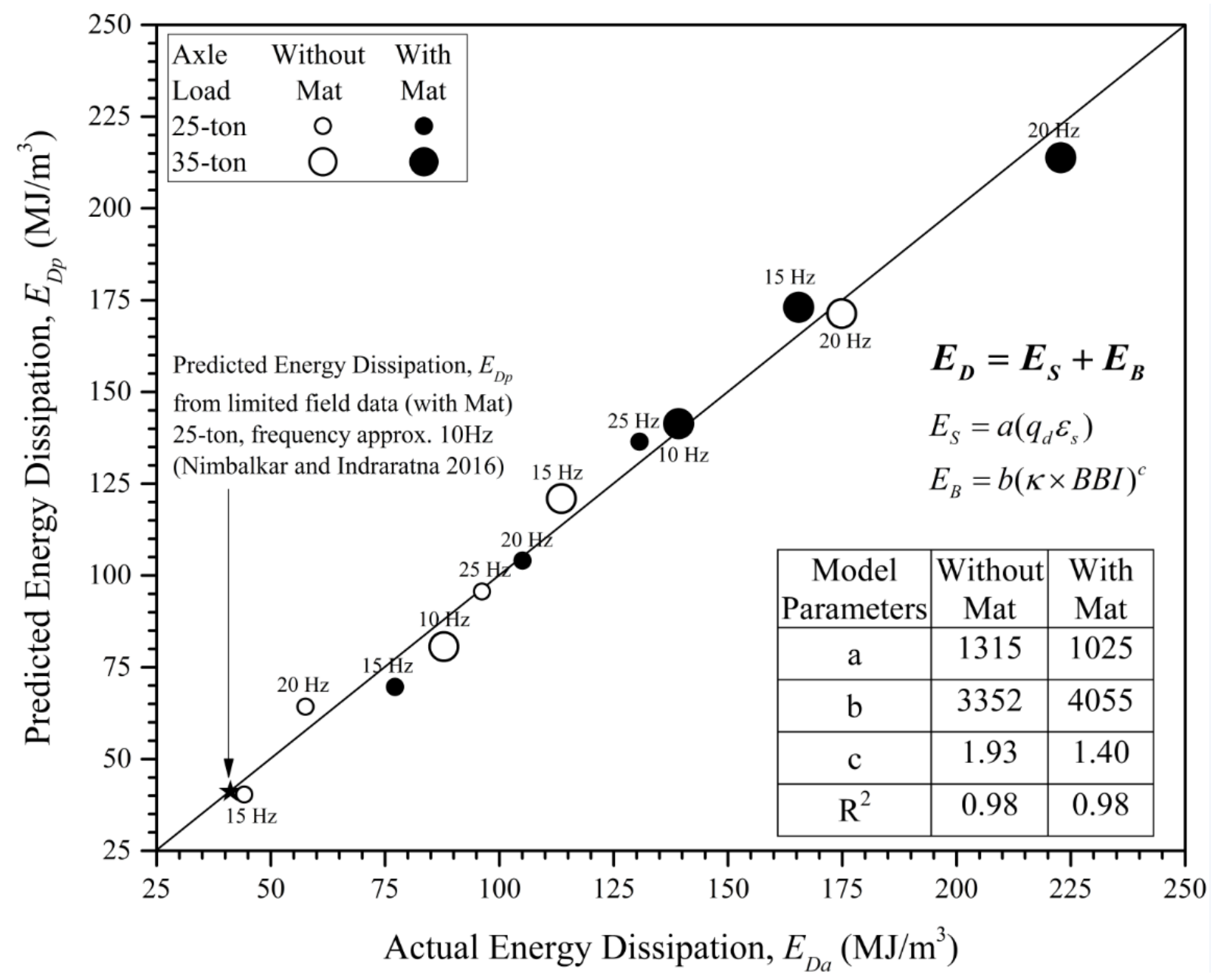

Fig. 17. Predicted and actual values of energy dissipation $\left(E_{D}\right)$ 